\title{
Climate Variability and Soil Nutrients Status along Altitudinal Gradient in Kigezi Highlands, Southwestern Uganda
}

\author{
Fortunate Twagiramaria*, Casim Umba Tolo \\ Department of Biology, Mbarara University of Science and Technology, Mbarara, Uganda \\ Email: *ftwagiramaria@yahoo.com, "ftwagiramaria@gmail.com, tolocas@must.ac.ug, \\ tolocas2000@yahoo.co.uk
}

Received 10 October 2015; accepted 10 January 2016; published 13 January 2016

Copyright @ 2016 by authors and Scientific Research Publishing Inc.

This work is licensed under the Creative Commons Attribution International License (CC BY). http://creativecommons.org/licenses/by/4.0/

(c) (i) Open Access

\section{Abstract}

Kigezi highlands currently experiences changes in precipitation and temperature which modify the evaporation and soil moisture storage leading to alterations in runoff and other components of hydrological systems. Extreme events, like floods and droughts, are more intense and frequent. Furthermore heavy unpredictable rainfall has become frequent in the area, causing soil erosion and floods that destroy crops. Soil erosion is particularly a pressing challenge due to steep-sided hills leading to deterioration of soil nutrients including soil fertility. The unpredictable rains and droughts are attributed to climate change and variability. Consequently, climate change and variability have caused a significant impact on soil nutrients which have affected the agricultural productivity in the area. This paper presents findings of empirical study which explored the climate variability and soil nutrient status along altitudinal gradient. The paper particularly addresses key questions of: land management practices in the study area, nutrient availability and their effects on productivity of selected crops along altitudinal gradient in changing climate and variability. Independent variables such as topographic sequence along altitudinal gradient were evaluated against dependent variables such as yield harvests of selected grown crops and soil nutrients. Samples for crop yields were collected along transect of 0.5 kilometer using a quadrant of $4 \times 4 \mathrm{~m}^{2}$ along attitudinal gradient. Soil samples were taken from selected plots at $0-20 \mathrm{~cm}$ soil depth for nutrient analysis. Analysis of physical and chemical soil parameters was carried out on soil samples and these include: soil $\mathrm{pH}$, soil organic content, total nitrogen, available soil phosphorous and exchangeable bases ( $\mathrm{Ca}, \mathrm{Mg}, \mathrm{K}$ and $\mathrm{Na}$ ). The study showed that middle parts of the transects had the highest concentration of most soil nutrients, probably because the middle parts could have been a deposition centre for some organic matter from the upper parts of the hills, and lower lying areas were being affected by floods that affects the decomposition of organic matter which is the main source of nutrients. Similarly, the middle parts of the study were the most fertile

${ }^{*}$ Corresponding author. 
due to the high concentration of soil nutrient compositions. This indicates that crop yields were significantly affected by availability of soil nutrients along same gradient, attributable to the severity in soil erosion, nutrients leaching and farming practices.

\title{
Keywords
}

\author{
Climate Change, Climate Variability, Soil Nutrients, Kigezi Highlands, Altitudinal Gradient, \\ Southwestern Uganda
}

\section{Introduction}

Erosion rate may be expected to increase in Kigezi highlands in response to current changes in temperature and precipitation due to climate change and variability. High temperatures modify the evaporation and soil moisture storage leading to alterations in runoff and other components of hydrological systems. Heavy unpredictable rainfall has become frequent in the area, causing floods and soil erosion that destroy crops [1]. Soil erosion is particularly a pressing challenge due to steep-sided hills leading to deterioration of soil nutrients including soil fertility [2].

Climate change refers to the change in the state of Climate that can be identified by changes in the mean and/or variability of its properties (including rainfall, temperature, solar radiations, wind, pressure and humidity) and that persists over an extended period of time typically decades or longer [3]. It refers to any change in climate over time whether by natural or human activity. By extended period of time, it means that the time element is long enough to have noticeable change. Variability implies the changes in the rainfall, temperature solar radiations, wind, pressure and humidity that are recorded over periods of 10 year not just months [4]. According to the UK Climate Impacts Program [5], climate refers to the average weather experienced over a long period, typically 30 years.

Climate change is recognized as one of the most serious global challenges of the $21^{\text {st }}$ century. Its multiple effects on basic human support systems such as agricultural production, forests, water resources and the ecosystem have largely affected farming systems [6]. Climate change effects on crop yields are expected to vary differently from region to region across the globe. Regions in high latitudes and around mountains which are affected by soil erosion during heavy rains are likely to have low agricultural due to erosion of soil nutrients [7], while in lower latitude regions, increased floods destroy crops and affects the process of soil nutrient recycling [8].

Climate change and variability are pressing challenges in Uganda. They affect natural resources particular soil fertility which is important in food production. About 1.5 billion metric tons of soil is lost every year from Uganda [2]. Productivity of the agricultural lands has been reduced as a result of declining of soil fertility. According to World Bank [2], an annual yield reduction of $1 \%-2 \%$ is estimated due to soil erosion in Uganda. The off-site effect of soil erosion has been also higher for highland area especially Kigezi highlands. Its negative effect will be more dangerous in the future particularly on steep-sided hills. The cost of climate change on nutrient status (because of soil erosion) in Uganda is very high [1] and will be worse in the future unless the situation is reversed. Following the heavy rains and extended droughts of Kigezi in 2004-2011, soil erosion has also land drawn the focus of most farmers in Kigezi [9].

In this paper, we explore the climate variability and soil nutrient status along altitudinal gradient. The paper particularly addresses key questions of: land management practices in the study area, nutrient availability and their effects on productivity of selected crops along altitudinal gradient in changing climate and variability.

\subsection{Land Management Practices in the Study Area}

Farmers have realized that climate variability especially heavy rains and prolonged droughts could have had a negative effect on nutrient reserves in their soils. As such, it is important that land be cared for in order to maintain or improve crop production levels [10]. Enyewe and Akalu [11] observed that land management practices improve crop production especially in hilly area. Mengele and Kirkby [12] suggested that cultivation of legumes favors the soils and other ecological settings of the area, legumes have advantage of nitrogen fixation. Legumes also have higher shoot to root ratio and leaves with low carbon to nitrogen ratio which makes them decompose quicker to release nutrients conserving the soil's nitrogen level. 


\subsection{Soil Nutrient Status along Altitudinal Gradients}

In America, Binkley and Sollins [13] established the fact that levels of nutrient availability decrease as altitude increases. This is particularly true for soluble nutrients such as potassium and nitrogen. Results of a study by Mulugeta and Stahr [14] in Highlands of Ethiopia also indicate that soils on steep areas are deficient in $\mathrm{K}^{+}, \mathrm{Ca}^{2+}$ and $\mathrm{Mg}^{2+}$. The use of NPK fetiliser has become more pronounced in cropping areas due to losses in Nitrogen, Phosphorous and Potassium in the face of erosion, leaching and evaporation [15]. Leaching of exchangeable ions due to climate change and variability has made the tops of some formerly productive steep areas such as Kenyan highlands less fertile requiring increased application of fertilizers [8]. The Uganda government advised farmers in raised areas to improve on their soil management practices in order to restore soil fertility [15]. Some farmers have slowly adhered to the message, especially those in areas that are regularly monitored by government authorities. In areas where government authorities are relaxed, the locals indeed continue not to care for the natural resources [16].

\subsection{Soil pH along Altitudinal Gradients}

Findings by Asadi et al. [17] show that highland areas have low levels of exchangeable ions of metals such as $\mathrm{Mg}^{2+}, \mathrm{Ca}^{2+}, \mathrm{K}^{+}$and are associated with alkaline $\mathrm{pH}$. This is due to loss of these nutrients by soil erosion or crop absorption, once the $\mathrm{pH}$ begins to decline soil become acidic. Mengele and Kirkby [12] assert that soil pH increases as one moves down slope. They attribute this to deposition of organic matter in low lying areas from higher altitudes. Their studies conducted in selected areas in Africa indicates that most hill tops are acidic while are low lying areas are alkaline if no crop farming is taking place. However, as climate change sets in, farmers attempt to grow crops on different parts of the slope. This consequently changes the $\mathrm{pH}$ of soils because of soil erosion when farmers are not practicing better farming methods [8]. Carswell [18] notes that Uganda's soils on sloping areas have higher acidity on the bottom part than the top parts. This has also determined the types and productivity of crops grown there.

\subsection{Soil Organic Matter Content Altitudinal Gradients}

Mati [8] asserts that organic matter content of soil decreases as altitude increases. Water erosion, which is a function of climate change, is a major contributor. The report explains that organic matter trends could change if cropping activities become more intense on lower altitudes. Siriri et al. [19] reported that in South western Uganda, organic carbon decreased down the terrace and higher organic carbon content was found at the upper side of the bund than the lower side especially during the rainy season. This could be due to the fact that farmers initially cropped on the lower lying areas, hence exhausting the organic matter there especially as population increases, which is the case in Kigezi region.

\subsection{Soil Texture Altitudinal Gradients}

Lilienfein et al. [20] assert that soil texture improves down slope. They explain that hill tops are associated with improperly weathered soils that are coarse. Higher altitudes are associated with low temperature and consequently low rates of rock weathering compared with lower areas. In the USA, raised lands have only recently become suitable for crops due to their poor soil texture characterized by rock particles [21]. Hamilton et al. [22] found more pollen grains of different crops on the lower ends of the slopes of Kigezi. Although erosion could have done a big part in transporting the grains down slope, the fact that poorly developed hill tops had unfavorable texture for crop growth was not ruled out. Soils on the upper parts of the hills were rough-textured. The particles mixed with pollen grains were easily carried down slope hence depositing more soil on the lower part of the hill.

\subsection{Crop Production in a Changing Climate along Altitudinal Gradients}

IPCC Predicts that Climate change is expected to cause a decline in food production in several highland areas especially in Africa [3]. This because climate change is often associated with extreme weather events like heavy rain fall which triggers disastrous soil erosion, landslides and flood along altitudinal gradients of highlands [8]. FOA [23] asserts that heavy rains and droughts alone have contributed to an annual loss in food production by over 30\% in highlands of Sub-Saharan Africa leading to hunger for the bigger part of the 1990s. Farmers in 
Uganda have pointed out that crop productivity is declining in highland areas due to the increasingly unpredictable rains being experienced [24]. Root crops such as potatoes, however, have shown a positive productivity trend which explains the relatively high yields of Irish potatoes in highland areas. Such crops probably resist droughts and heavy rains because their harvestable part is below the ground hence surviving changes in weather conditions. Some cereals such as sorghum (Sorghum vulgare), maize (Zea mays) and wheat (Triticum aestivum) in highland ecosystems of Mbale, Kapchorwa, Kisoro and Kabale have also shown somewhat stable productivity amidst varying and changing climate [25]. This could be mainly due to fluctuating soil moisture supply and environmental temperature which affect crop yield. Highlands in western Uganda are affected by soil erosion which is caused by heavy rains. About 5 tonnes ha ${ }^{-1}$ of soil are lost each year leading to nutrient losses (nitrogen, potassium and phosphorus at rate of 85,75 , and $10 \mathrm{~kg} \cdot \mathrm{ha}^{-1} \cdot \mathrm{year}^{-1}$ respectively) hence reduced soil productivity leading to low crop yield [2].

\section{Materials and Methods}

\subsection{Location of the Study Area}

This study was conducted in Kabale district in south western Uganda representing Kisoro, Kabale, Rukungiri and Kanungu (Kigezi region). It lies between $29^{\circ} 45^{\prime}$ and $30^{\circ} 15^{\prime}$ East and $1^{\circ} 00^{\prime}$ and $1^{\circ} 29^{\prime}$ South. It borders with the districts of Kisoro in the West, Rukungiri to the North, Ntungamo to the East and the Republic of Rwanda to the South (Figure 1). It is located about 400 kilometers from Kampala, Uganda's capital city. Kabale district covers a total surface area of $1827 \mathrm{Km}^{2}, 93 \%$ of which is arable land [19]. It is a highland area with steep slopes, intensely cropped hillsides and high population densities. Many aspects of the Kabale agro-ecosystem are similar to other highlands in Uganda [26]. The district was purposively selected because it has many similarities of other many agro-ecosystem highlands of Kigezi.

\subsubsection{The Study Sites}

This study was carried out in three Parishes located in two neighbouring sub counties of Muko and Bufundi. The parishes selected were Karengyere and Ikamiro (in Muko Sub-County) and Kacherere (in Bufundi Sub-County, Figure 2). Purposive sampling was used since the parishes have different altitudinal locations hence expected to have differences in soil fertility and potentially different crop productivity. The Parishes were also selected purposively due to the fact that most of the local people were involved in crop farming.

\subsubsection{Climate of the Study Area}

The study area receives an annual rainfall between 1000 and $1500 \mathrm{~mm}$ of rain, and has two rainy seasons. The first main rain is from August to December and the second is short rains are from March to May. It also has two dry seasons that is in January and between June and July. The mean temperature is $18^{\circ} \mathrm{C}$ with maximum of $24.4^{\circ} \mathrm{C}$ and minimum of $10.9^{\circ} \mathrm{C}$ and the relative humidity ranges between $90 \%-100 \%$ in the mornings and decreases to $42 \%-75 \%$ in the afternoons throughout the year. The mean monthly maximum and minimum temperatures are 24.1 and $11.6^{\circ} \mathrm{C}$ respectively (Figure 3). However, the rainfall totals vary from year to year (Figure 4) due to climate variability and change. These seasons have been disrupted especially for the last ten years [29].

Figure 3 indicates that there are two seasons, the warm and the cool seasons. The warm (dry) seasons are characterized of high maximum temperatures always experienced during the day time, while the minimum temperatures are always experienced during the nights of the corresponding days. Cool months (corresponding to wet season) such as November and December as well as March and April are characterized of low maximum temperature (during the day) and slightly higher minimum temperatures (during the nights). As relates to farming, the farmers prefer to plant their seeds during the months with lower maximum (day-time) temperature to minimize transpiration and water stress among crops.

Figure 4 shows fluctuating rainfall amounts in different years. This could confirm why farmers have gradually abandoned some crops (heavy rainfall and drought vulnerable varieties) and adapted to quicker maturing ones and root crops. In 2003 and 2008 farmers could have been disturbed with a lot of rainfall, and again disturbed with extremely low rainfall in 2000 and 2005. Some farmers with knowledge on soil and water conservation could, however, continue growing all the crops by practicing techniques such as early planting, mulching and growing shorter maturing varieties alongside root crops. 


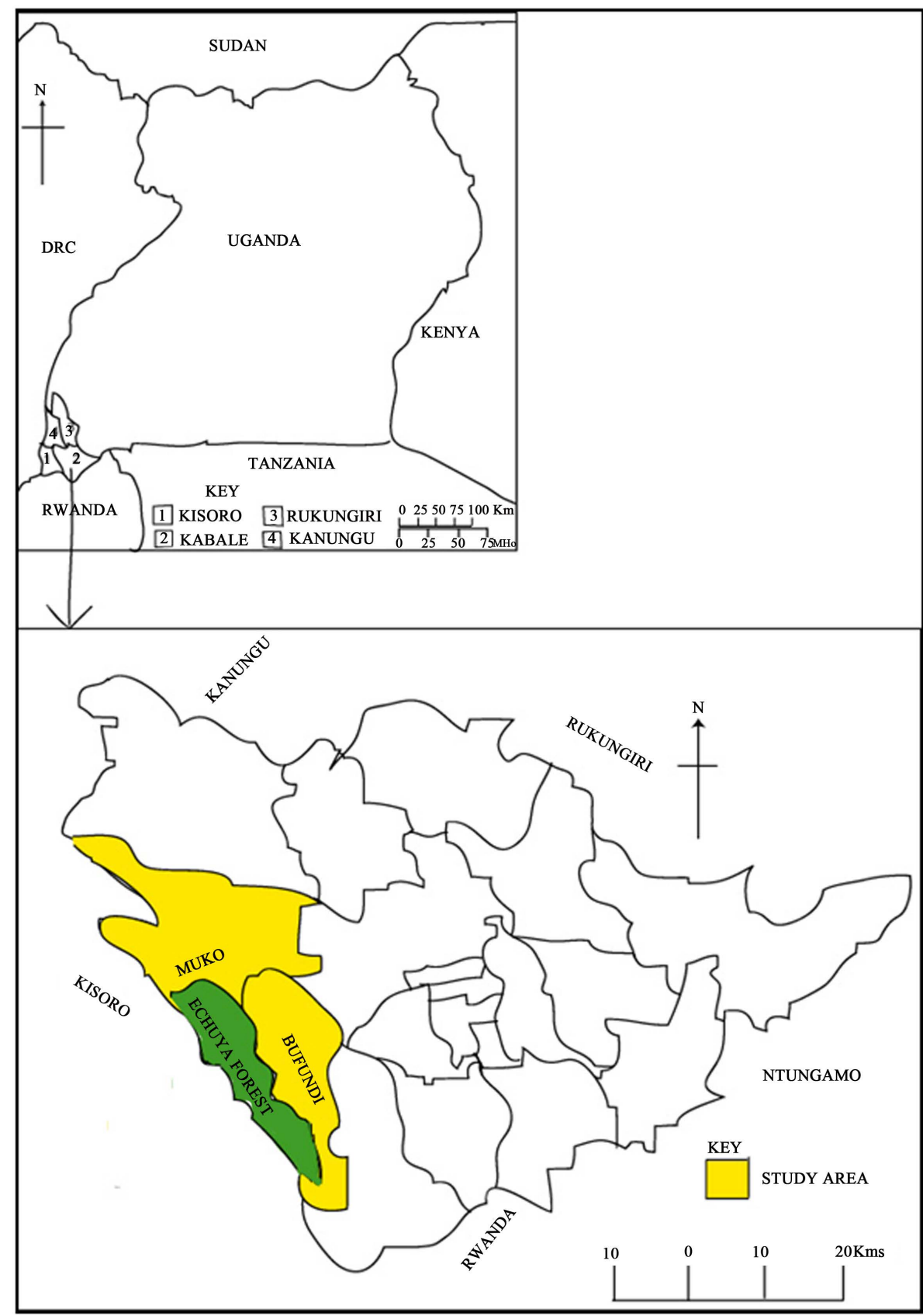

Figure 1. Location of study areas in Kabale District, Kigezi region South Western Uganda. Source: Ministry of Natural Resources, Kabale district [27].

\subsubsection{Vegetation Cover of the Study Area}

The original vegetation cover of the study area has been cleared for crop production and pasture. There is hardly any natural vegetation cover in areas outside the protected areas. Some hills have been planted with Eucalyptus grandis. Most swamps in the valleys have been drained to increase the acreage of cropland and pasture for animals. Clearing of forests for crop cultivation and livestock grazing started as early as 2200 to 4800 years ago [16]. Though the ecosystems changes naturally, climate change and human activities have generally changed the ecosystems in the area [22]. The vegetation currently comprises of trees, shrubs, herbs and lianas with trees the most dominant followed by herbs and lianas. The dominant tree species in the study area include Eucalyptus grandis (exotic), Ficus natalensis. Some of these trees are grown for economical and ornamental purposes. The 


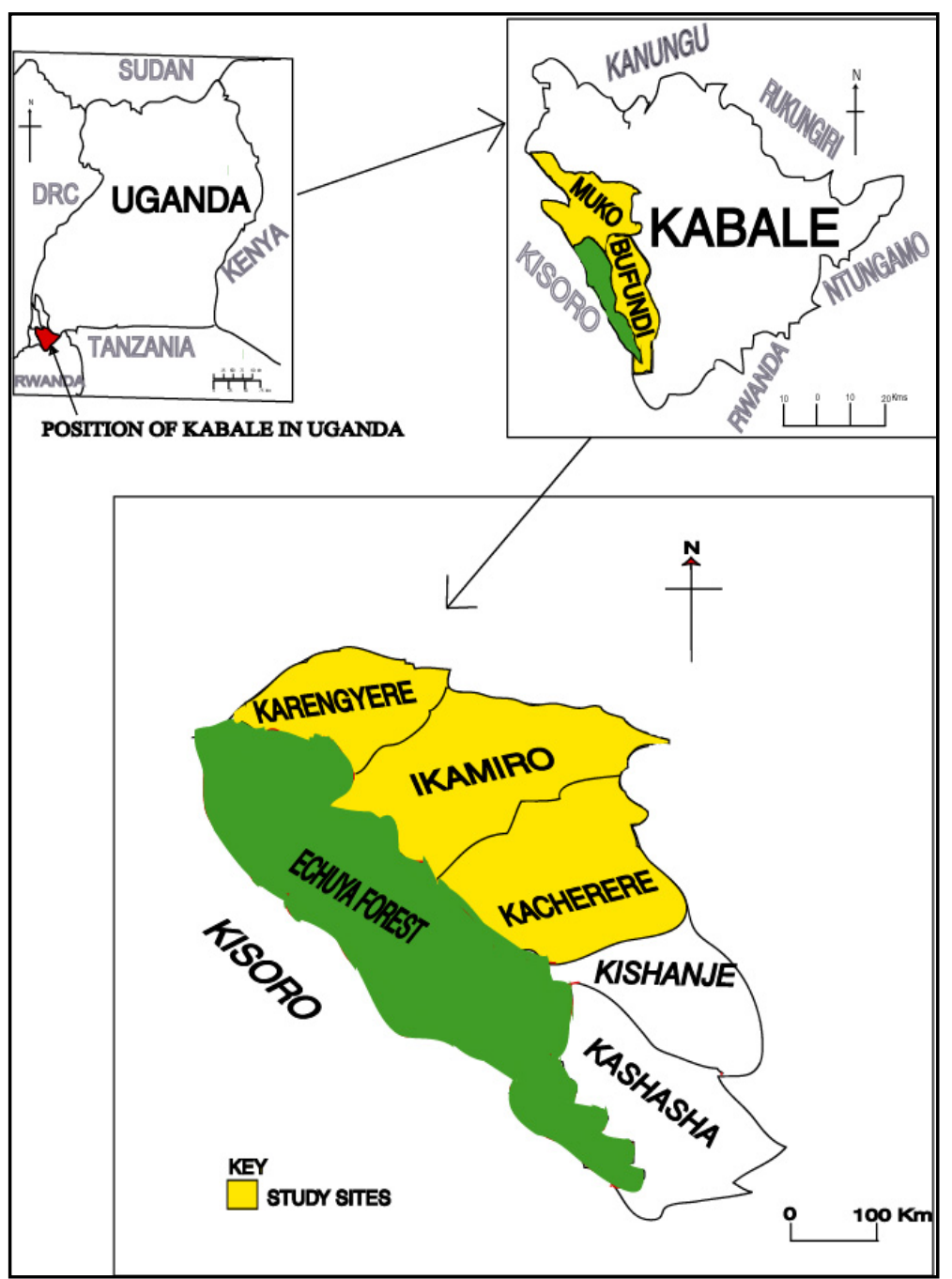

Figure 2. Location of study sites from Kabale district South Western Uganda. Source: Modified from Banana and Tweheyo [28].

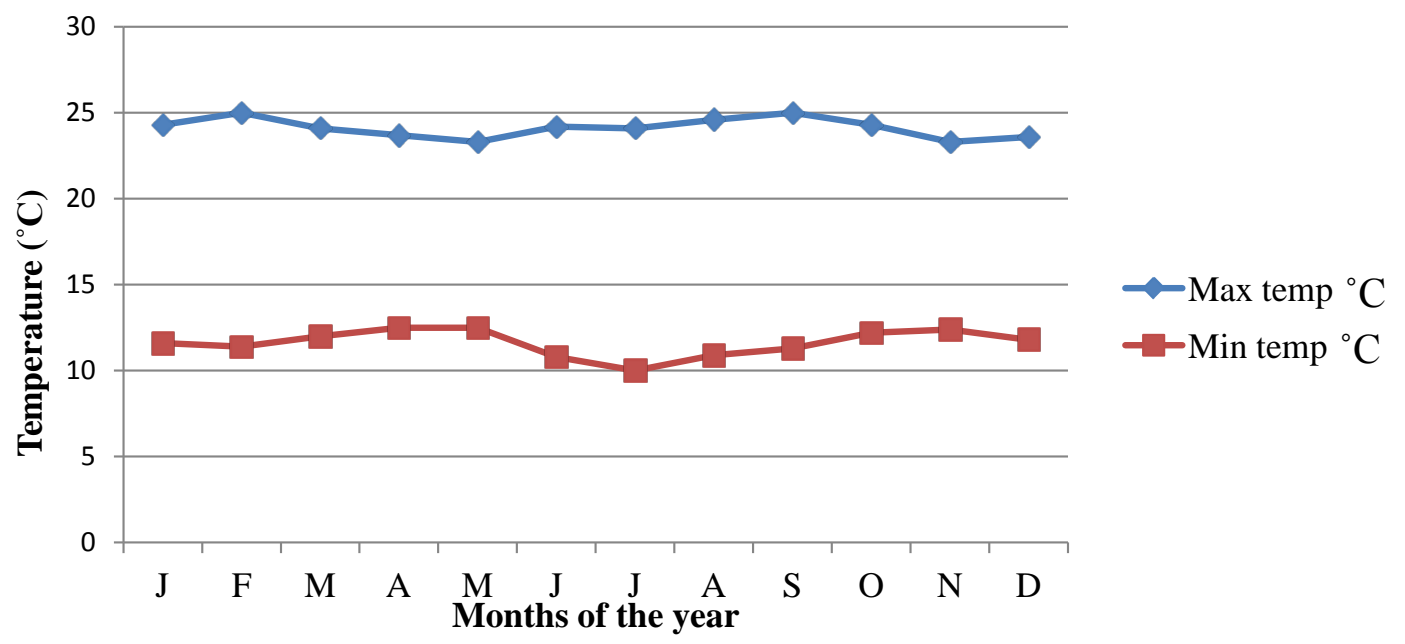

Figure 3. Mean annual monthly maximum and minimum temperatures for Kabale, 1994-2011. Source: Kabale District Meteorological Department [29]. 


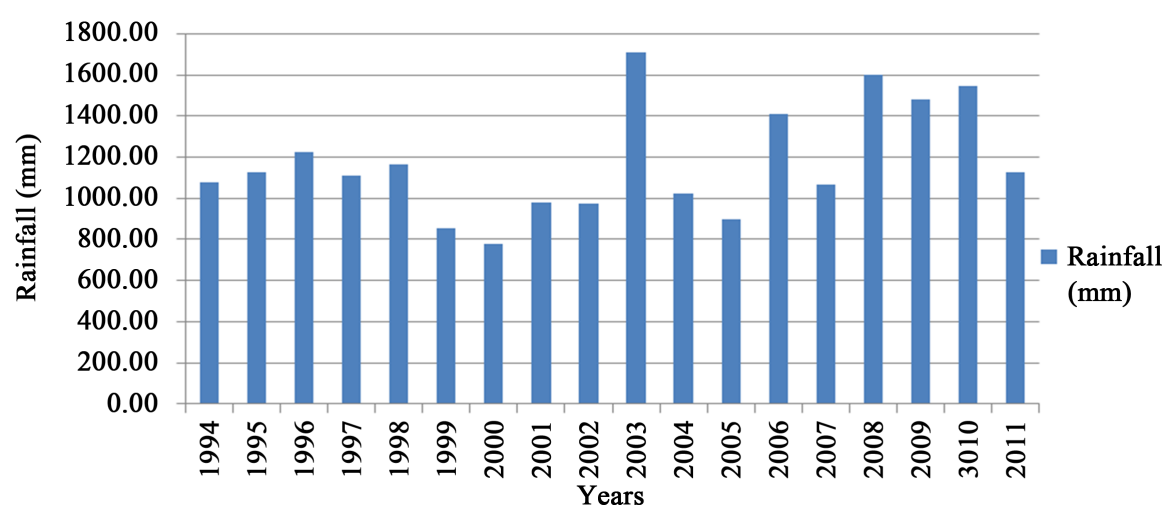

Figure 4. Mean annual rainfall for Kabale, 1994-2011. Source: Kabale district Meteorological Department [29].

common shrubs in the area include Lantana camara, Desmodium species, Venoniaamy dalina and Solanum incanum. The most common herbs are: Solanum nigrum, Helianthus anus, Bidens grandi, Bidens pilosa, Oxalis corniculata and Galinsoga parviflora. Most of these plants are weeds in uncultivated and cultivated garden [10].

\subsection{Research Design}

The data on crop yield were collected in two successive planting seasons of the years 2012 and 2013. The first season was in July 2012 and the second season in Jan. 2013. This was important since the study area had two planting seasons in the year for some crops. One hill which was dominated by the cultivation of the identified crops in each village was selected and its altitude was determined and recorded. Different farming practices were identified and recorded. An altitude reading on each part was determined using a Global Positioning System, GPS (Garmini GPS II).

A transect running from the bottom to the top was set on each selected hill of the study area in a south-north direction. A total of three transects were set in whole study area. Thirty four plots (twelve for Irish potato (Solanum tuberosum), twelve for beans (Phaseolus vulgaris) for two seasons, and four for sweet potato (Ipomoea batatas), and 6 plots for sorghum (Sorghum vulgare) for one season) were set from each transect making a total of 102 plots (Appendices 1-3). The plots were distributed along altitudinal range of the hill (i.e. lowest altitude, middle altitude and the highest altitude).

Data on crop yield were collected and recorded from all plots in two seasons (for Irish potato and beans) and for one season for sorghum and sweet potato. These rounds of data collection corresponded with the respective growing seasons for the crops. The selected gardens had pure stands of the common crops grown in a changing climate; facilitated by the traditional and common farming practices in the area. Independent variables such as positions in topographic sequence in the study area were evaluated. Dependent variables measured were; yield harvests of the selected common crops grown and soil nutrients. It was assumed that there were no significant differences in the climatic conditions of all the sites. Meteorological data was collected from Kabale District Meteorological Department (Figure 3 and Figure 4). The data concerning the weather for year the 2012 was obtained from Karengyere Weather Station.

\subsection{Research Procedure}

An introduction letter was obtained from Mbarara University of Science and Technology, Faculty of Science. Then, it was taken to the sub-county chiefs of the selected sub counties. The sub county chiefs granted the researcher permission to conduct the study in their respective Sub-Counties. Sampled areas were visited; appointments were made on when to carrying out field observations, and collecting data on crop yield and soil samples.

\subsection{Sampling Procedures}

To investigate the crop yields of identified crops per hectare, transect lines were established along altitudinal gradients of the hills selected. Three transect lines, each having the length of $500 \mathrm{~m}$, were established in the 
study area. Transects were positioned using a compass and marked with stakes and flagging tapes. Global Positioning System (GPS) was used to identify the geographical locations and altitude (metres above sea level) of the respective sampling sites. Sampling points were systematically established at regular intervals (Figure 5). Thirty four plots (for all the identified crops) were selected from each transect on the hill. Twelve plots were for Irish potatoes, where six plots were for first season and other six were for the second season (two were plots from each part of the hill). The same was also done for beans since they were also grown in two seasons of the year. For sweet potatoes, four samples (two from the middle and two from the top parts of the hill) were taken in one season of the year. Sweet potatoes were not grown in the lower part of the transect. For sorghum, six samples were picked (two from each of the three parts of the transect). These plots were at different altitudes: the lowest, the middle, and the highest parts of the hill.

Samples for crop yield data were collected using quadrants of $4 \times 4 \mathrm{~m}^{2}$ for all the crops at lower, middle and upper parts of the hill (Figure 5). The same sampling technique was done in all the three transects making a total of 102 plots sampled (from the three transects).

The yield from each crop was weighed (in $\mathrm{Kg}$ ) and the result recorded. A spring balance was used to take the measurements. For Irish potato and beans the records were taken twice (two seasons). The harvests for first season were taken from June to July of 2012 and those for second season were taken from December (2012) to January (2013). For sorghum and sweet potato, the weights were taken once following their respective periods of harvest (in July and December, 2012 respectively). Measurements were done in the field for better validity.

\subsection{Soil Sampling for Nutrient Determination along Altitudinal Gradients of the Hills}

To determine the status of major soil nutrients (organic carbon, soil pH, total nitrogen, available soil phosphorus and exchangeable cations) required by the identified crops, soil samples were collected from the plots of the selected crops. From each plot, two soil samples were randomly collected. These made a total of sixty eight samples from thirty four plots of selected crops per transect: taken from lower, middle and upper part (Figure 5) and a grand total of 204 samples from the three transects.

A soil shovel was used to extract samples at a uniform depth of $20 \mathrm{~cm}$ from the selected sites. During collection of samples, dead plants, furrow, old manure sites, wet spots, areas near trees and compost pits were excluded. This was done to minimize differences, which may arise because of the dilution of soil organic matter due to mixing through cultivation and other factors. The soil was air dried to minimize transformation. The dry samples were sieved through a $2 \mathrm{~mm}$ screen to remove undesirable objects such as grass and stones. The samples were then transported to the soil testing facilities at the Department of Soil Science, Faculty of Agriculture, Makerere University for analysis.

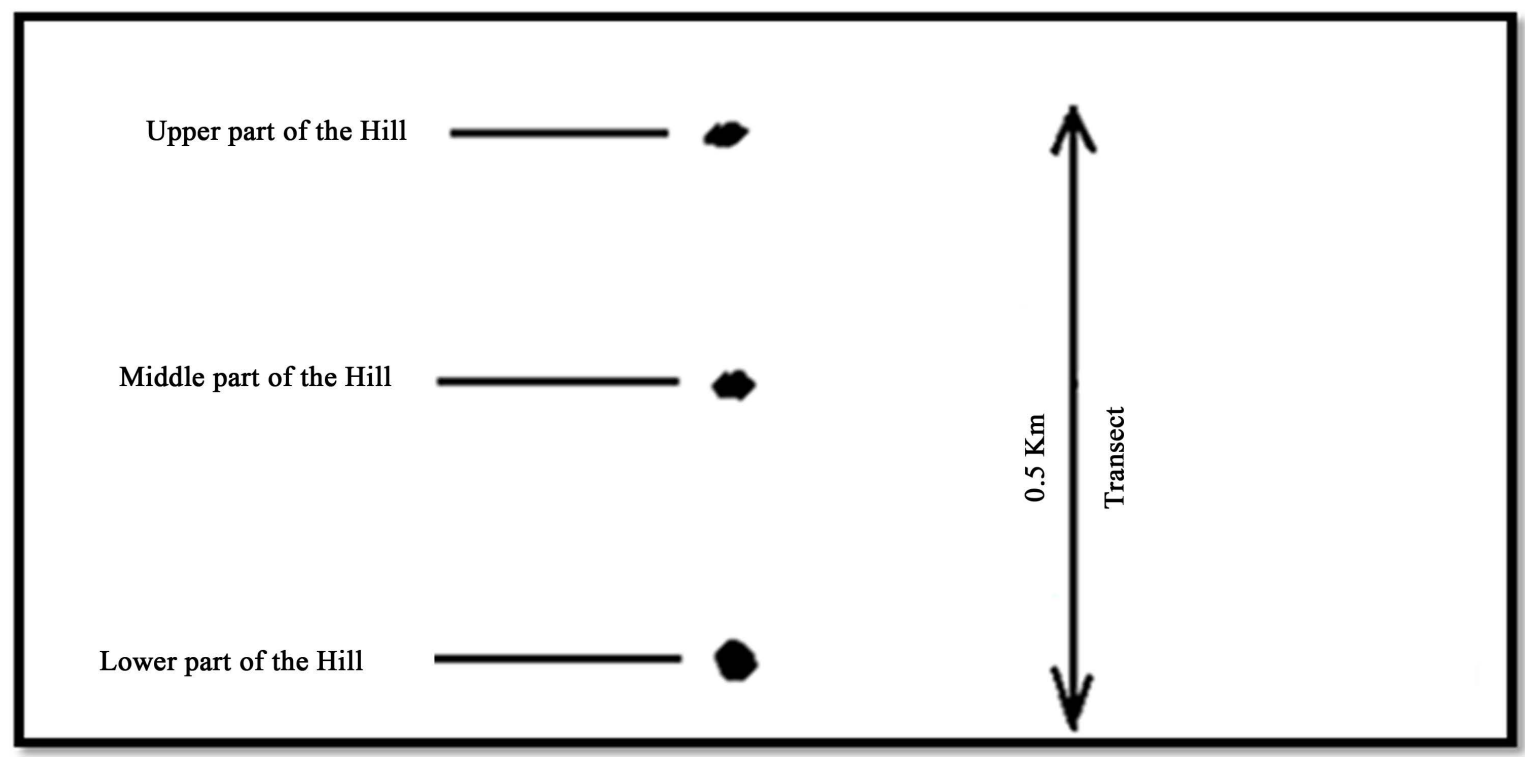

Figure 5. Soil and crop sampling points along transects in study area. Source: Field data, 2012. 


\subsection{Soil Laboratory Analysis}

The soil physical and chemical analysis was carried out at the Department of Soil Science, Faculty of Agriculture, Makerere University. Laboratory procedures followed in the analysis of the selected physicochemical properties considered in the study included the following:

The $\mathrm{pH}$ of the soils was measured in water and potassium chloride $(1 \mathrm{M} \mathrm{KCl})$ suspension in a 1:2.5 (soil: liquid ratio) potentiometrically using a glass-calomel combination electrode [30]. The Walkley and Black [31] wet digestion method was used to determine soil organic content and percent soil organic matter was obtained by multiplying percent soil organic content by a factor of 1.724 following the assumptions that organic matter is composed of 58\% carbon. Total Nitrogen was analyzed using a Blocker digester, distillation and titration method as described by Black [31] by oxidizing the organic matter in concentrated sulfuric acid solution (0.1 M $\mathrm{H}_{2} \mathrm{SO}_{4}$ ). Available soil Phosphorous was analyzed according to the standard procedure of Olsen et al. [32] extraction method.

Exchangeable bases ( $\mathrm{Ca}, \mathrm{Mg}, \mathrm{K}$ and $\mathrm{Na}$ ) were determined after extracting the soil samples by ammonium acetate $\left(1 \mathrm{M} \mathrm{NH} \mathrm{N}_{4} \mathrm{OAc}\right)$ at $\mathrm{pH}$ 7.0. Exchangeable Calcium and Magnesium in the extracts was analyzed using atomic absorption spectrophotometer, while Sodium and Potassium were analyzed by flame photometer [33]. Percentage base saturation (PBS) was calculated by dividing the sum of the charge equivalents of the base-forming cations (Ca, Mg, Na and K) by the CEC of the soil and multiplying by 100.9.

\subsection{Data Analysis}

Quantitative data about soil nutrient status and crop yield were entered without further manipulation. The soil chemical properties were subjected to analysis of variance. SPSS (version 17.0) program was used to analyze the data. Student's t-test was applied for assessing the significant differences between the mean values of soil properties and crop production between two different parts. For data containing more than two variables, analysis of variance (ANOVA) was carried out to determine the presence of significant differences among the treatments using SPSS version 17.0. The least significance difference (LSD) test was used to determine the significant difference of nutrients on different parts of the hill and crop production (transect).

\section{Results and Discussion}

\subsection{Land Use and Management Practices in the Study Area}

The most common land management practices observed during the study the study area were: Planting of improved crop varieties (18.32\%), contour ploughing shown in Figures 6-8 (17.28\%), use of inorganic fertilizers and agro-chemicals (herbicides, pesticides, and fungicides) 16.75\%, mixed cropping (10.47\%), crop rotation and

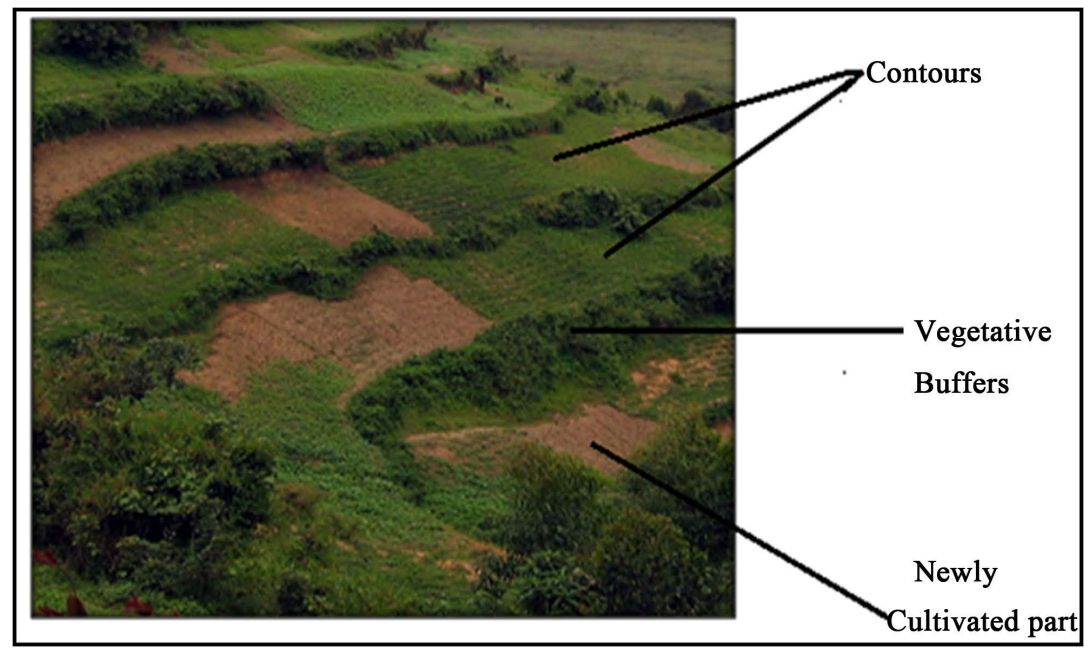

Figure 6. Land use and management practices in the upper parts of the hill in Karengyere Parish, Muko Sub-County (source: Field photo, 2012). 


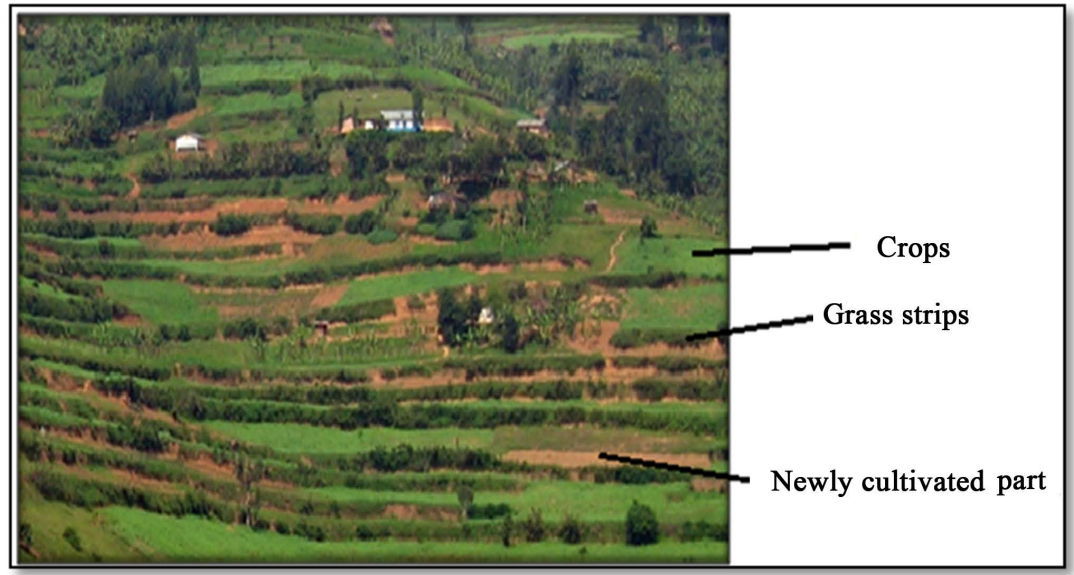

Figure 7. Land use and management practices in the middle part of the hill in Ikamiro Parish, Muko Sub-County (source: Field photo, 2012).

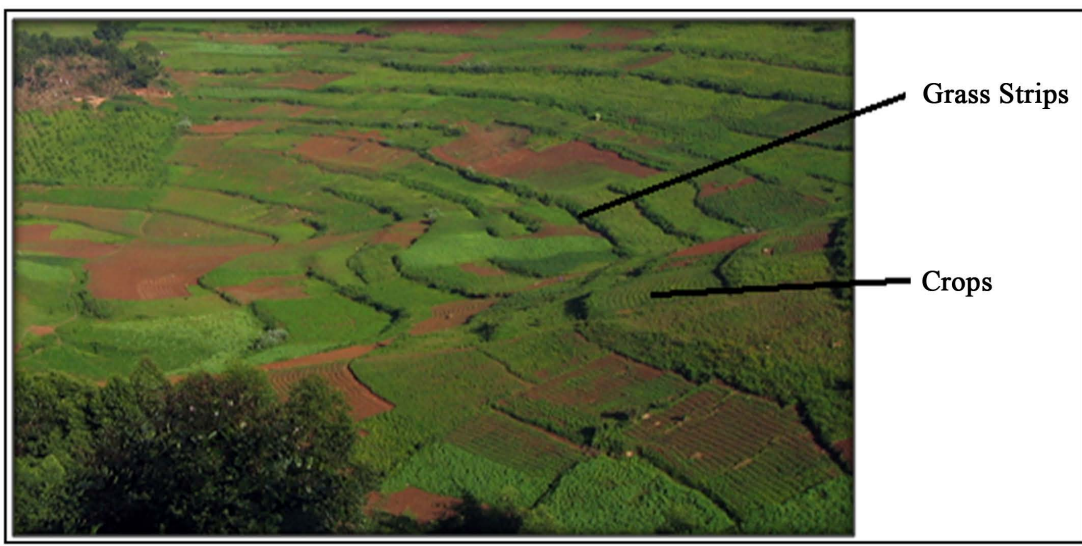

Figure 8. Land use and management practices in the lower parts of the hill in Kacherere Parish, Bufundi Sub-County (source: Field photo, 2012).

planting legumes (9.41\%), trash lines incorporation of crop residues (7.33\% ), grass strips and vegetative buffers, locally known as "Kati kakingo" (6.28\%), application of farmyard or compost manure (3.14\%), intercropping (5.24\%). Other practices (5.76\%) such as stone barrages, fallowing and minimum tillage were also mentioned as summarized in Table 1. The findings and observations by Bamwerinde et al. [10] and Siriri et al. [19] shows that farmers have realized that climate variability especially heavy rains and prolonged droughts could have had a negative effect on nutrient reserves in their soils. As such, it is important that land be cared for in order to maintain or improve crop production levels (and household food and income security). Enyewe and Akalu [11], just like observations in the study area (Table 1), agrees that mulching could conserve moisture and nutrients in the soil. Although this practice was observed in the study area, most crops (including Irish potato and beans) were not favoured by the practice. Mulching is only done for cabbage and tomato which are less important (compared to beans and Irish Potato) in terms of food security. It is therefore important that other practices such as intercropping and application of manures be embraced by all the farmers.

The cultivation of legumes was also observed (Table 1). Apart from being favoured by the soils and other ecological settings of the area, legumes had an added advantage of nitrogen fixation as earlier suggested by Mengele and Kirkby [12]. A number of legumes including beans and field peas are dominant in the study area as they save farmers a great deal of expenses in maintaining soil fertility. Legumes also have higher shoot to root ratio and leaves with low carbon to nitrogen ratio which makes them decompose quicker to release nutrients conserving the soil's nitrogen level.

Other practices such as trash lines, and application of compost and farm yard manure were also observed (Table 1). Such organic farming practices are more sustainable and affordable to most farmers in the study area. 
Table 1. Land use and management practices in the study area.

\begin{tabular}{ccc}
\hline Land management practices & Frequency & Percentages (\%) \\
\hline Improved crop varieties and planting legumes & 35 & 18.32 \\
Contour ploughing & 33 & 17.28 \\
Use of inorganic fertilizer and agro-chemicals & 32 & 16.75 \\
Mixed cropping & 20 & 10.47 \\
Crop rotation and planting legumes & 18 & 9.41 \\
Trash lines (incorporation of crop residues) and mulching & 14 & 7.33 \\
Grass Strips and Vegetative Buffers & 12 & 6.28 \\
Application of animal or compost manure & 11 & 5.76 \\
Intercropping & 10 & 5.24 \\
Others & 6 & 3.14 \\
\hline
\end{tabular}

Source: Survey data, 2012.

Such inputs are slow releasers of crop nutrients (especially $\mathrm{Ca}, \mathrm{Mg}$ and $\mathrm{N}$ ) and also improve soil structure making soil particles somehow sticky to each other and resistant to erosion. Most farmers were using improved varieties because of accessibility to agriculture research Centre at Karengyere where they get extension services. Few farmers were practicing intercropping because different crops have different planting and harvesting dates as well as different field requirements. The fact that farmers were able to practice the farming strategies in Table 1 shows their ability to choose appropriate practices in consideration to climatic change and variability, land slope, crops grown and their own financial abilities.

\subsection{Major Crops That Are Grown in the Study Area}

At the time of the study, the commonest grown crops in Kigezi highlands were: Irish potatoes, beans, sweet potatoes, sorghum, maize and others like vegetables. Some crops are no longer grown or are grown only a few farmers due to climate change and variability which leads to loss of soil nutrients, pests and diseases.

Findings of the study in Kabale and FAO [23] and Desanker [34] recommend the growing of root crops since they survive better in changing climate. Figure 9 showed that root crops (Irish potato and sweet potato) have replaced cereals (wheat and rice) that had been dominating the food and income baskets of the area in 1970s. This may be one of the reasons why some farmers have changed their cropping options to have the crops that can survive the prevailing conditions today. Root crops have better resilience to hot temperatures, and erratic rains. This could be because the commercial yield for these crops is underground (roots) which means that they are less affected by environmental temperature changes, such as extreme coldness and hotness, heavy rains and sun scorch. Such crops also resist foliar diseases such as blights which harassed the cereals. They also allow piece-meal harvesting which makes them more dependable for food security. The study findings and FAO [23] agree that growing of legumes (beans) has persisted throughout the period of changing climate. This could be due to the fact legumes help to improve the soil's nitrogen base while also serving as sauce as company for the root crops.

\subsection{The Status of the Soil Nutrients Required by the Identified Crops in along Altitudinal Gradient}

The study investigated the status of the soil nutrients required by the identified crops in changing climate along altitudinal gradient. This was intended to help find out whether the soil conservation practices being carried out in the area were controlling land degradation (soil erosion) which is a pressing challenge during changing climate and variability to farmers. 

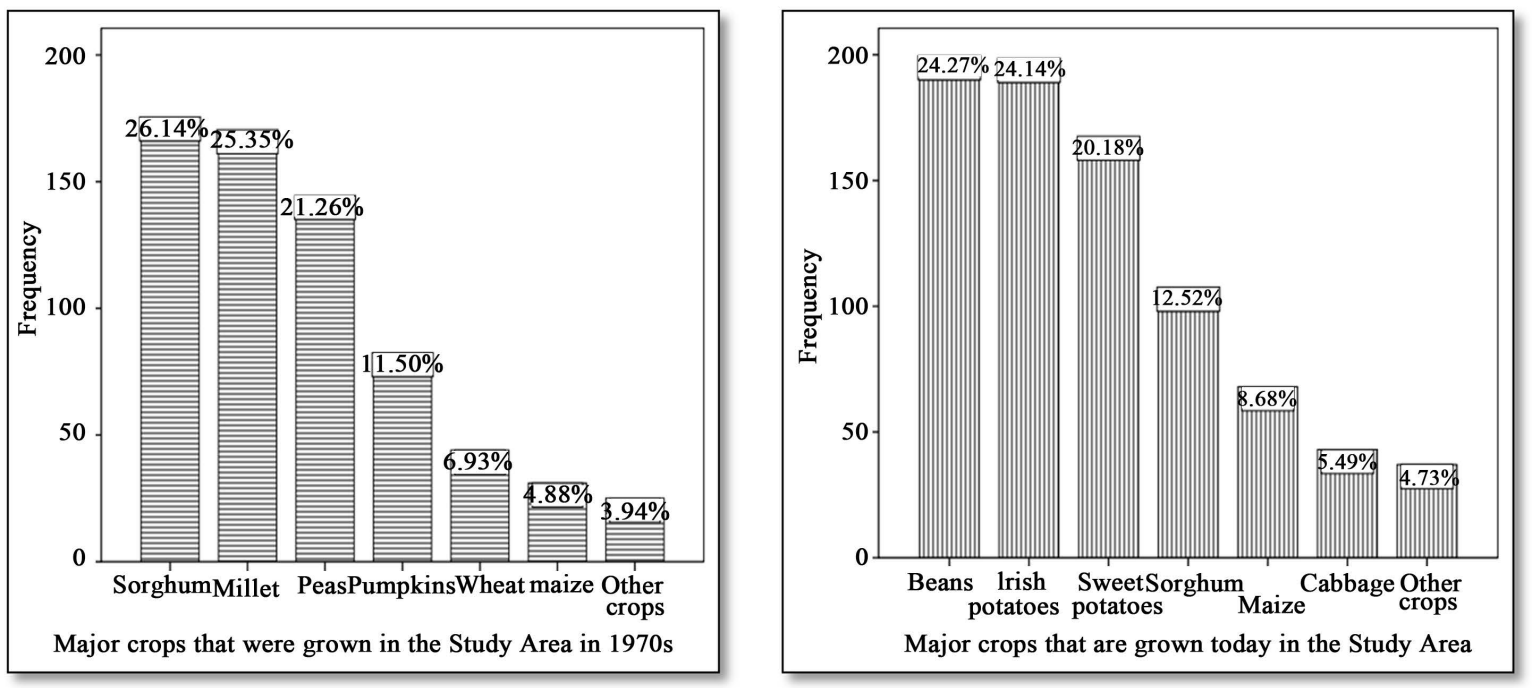

Figure 9. Major crops grown in the study area in a changing climate and variability. Source: Survey data, 2012.

\subsubsection{Soil pH}

The soil analysis results in (Table 2) showed that Karengyere had highest $\mathrm{pH}$ (6.4) in the lower parts and middle parts had the lowest $\mathrm{pH}$ (5.3). There was a significant difference in $\mathrm{pH}(\mathrm{F}=34.619, \mathrm{df}=2, P=0.01)$ between the lower and the middle parts. However there was no significant difference $(P=0.13)$ between the pH in middle and upper parts. The study also showed that Ikamiro had highest $\mathrm{pH}$ (5.5) in the upper parts and middle parts had the lowest $\mathrm{pH}$ (4.9). It also showed a significant difference $(\mathrm{F}=5.191 \mathrm{df}=2, P=0.04)$ for the soil $\mathrm{pH}$ of lower, middle and upper parts. Again there was a significant difference $(P=0.02)$ between middle and lower parts of the hill and no significant difference $(P=0.18)$ between middle and upper parts of the hill. Kacherere soil was moderately acidic ( $\mathrm{pH} 5.6$ - 6.0), where the mean $\mathrm{pH}$ values were: 5.1, 6.1, and 6.0 for the lower, middle and upper parts respectively. There was a significant difference $(\mathrm{F}=21.00 \mathrm{df}=2, P=0.02)$ between the $\mathrm{pH}$ of the lower part, middle and upper part. There was no significant difference $(P=0.58)$ between the $\mathrm{pH}$ of the middle part and upper part (Table 2). The statistically mean value of soil $\mathrm{pH}$ for the Karengyere, Ikamiro and Kacherere hills showed no significant difference $(\mathrm{F}=5.061$, $\mathrm{df}=2, P=0.15)$.

This finding is contrary to assertions by Asadi et al. [17], Carswell [19], and Mati [8] that low lying areas initially have high levels of exchangeable cations creating an alkaline $\mathrm{pH}$ which trend changes once leaching and crop uptake reduce the quantities of the nutrients in the soil. However, they are in agreement with Mengele and Kirkby [12] who observe that low lying areas are initially acidic. Although the lower and middle parts had more organic matter content, it did not necessarily result into an alkaline $\mathrm{pH}$ of the soil. The reason could be that the cultivated crops selectively absorbed certain exchangeable ions which had to be replaced with hydrogen or other ions, hence a variation in soil $\mathrm{pH}$. In addition to this, the formation of humic acid is yet another possibility especially on the upper part of Ikamiro, the lower part of Kacherere and the middle part of Karengyere. Variations in soil $\mathrm{pH}$ could have come as a result of differential treatment of soils with agro-chemicals such inorganic fertilizers, and fungicides as commonly observed practiced in the area by the different farmers. Such farming practices lead to changes in soil $\mathrm{pH}$.

\subsubsection{Soil Organic Matter}

This study revealed that Karengyere had the highest percentage of the organic content in the middle part of the hill $(0.21 \%)$ followed by the lower part which had a percentage of $0.17 \%$ percent and the upper part had lowest percentage $(0.12 \%)$. The soil organic matter content of Karengyere hill statistically showed a significant difference $(\mathrm{F}=24.926$, $\mathrm{df}=2, P=0.01$ ) between the lower, middle and upper parts of the hill, and there was no significant difference $(P=0.11)$ in the organic content between middle and upper parts of hill. In Ikamiro parish the highest percentage of the organic content was found at the upper part of the hill $(0.24 \%)$, followed by the lower part which had a percentage of $0.19 \%$, and the middle part had lowest percentage $(0.17 \%)$. There was no significant difference $(\mathrm{F}=9.00, \mathrm{df}=2, P=0.16)$ in the organic content between lower, middle and upper parts 
Table 2. Soil pH of the study area.

\begin{tabular}{cccc}
\hline Part of the Hills & $\mathrm{pH}$ in Karengyere & $\mathrm{pH}$ in Ikamiro & $\mathrm{pH}$ in Kacherere \\
\hline Upper & 5.8 & 5.5 & 6.0 \\
Middle & 5.3 & 4.9 & 6.1 \\
Lower & 6.4 & 5.2 & 5.1 \\
\hline
\end{tabular}

Source: Field data 2012.

of hill. Kacherere had the highest percentage of the organic content in the middle part of the hill $(0.17 \%)$, followed by the lower part which had a percentage of $0.13 \%$ and the upper part had the lowest percentage $0.11 \%$. There was also significant difference $(\mathrm{F}=6.462, \mathrm{df}=2, P=0.03$ ) for organic content in lower, middle and upper parts of Kacherere hill.

The findings, Asadi et al. [17] and Mati [8] agree that the amount of organic content are high in the middle followed by the lower and the upper parts of the hills have the lowest total percentage of the organic contents. Indeed, the middle parts could have been a deposition centre for some organic matter from the upper parts of the hill. However, in relation to climate variability and change, this could be an indicator that lower lying areas are being affected by floods especially following Uganda government caution to people in low lying areas to vacate them after the Buduuda (Eastern Uganda) landslides [35]. High organic matter contents are associated with high nutrient mineral release and better soil structure (and reduced leaching) as well as high soil moisture conservation potentials hence overcoming short droughts and effects of rain spells as well.

The trend for Ikamiro, was however different, with the highest organic matter content found on the upper part. This could be because of the human settlement and crop farming activities carried out there, which is in agreement with FAO [23] which states that most farmers in Africa the area are peasants and cannot afford to use inorganic fertilizers, hence resorted to use of manures resulting into higher organic matter content of their soils. The use of these manures is indication that soils were becoming less fertile probably due to leaching and nutrient evaporation both of which are functions of climate change. Bamwerinde et al. [10] asserts that amount of soil organic matter reduces with continued cultivation. This is likely since the organic matter breaks down due microbial decomposition and releases nutrients that are taken by plants, leached or eroded. This proposition could be true as revealed in the study area.

\subsubsection{Total Nitrogen}

In this study, it was found that Karengyere had the highest total Nitrogen levels in the middle part (3.6\%) followed by the lower part (2.8\%) and the upper parts of hill had the lowest (1.4\%). There was a significant difference $(\mathrm{F}=82.5 .26, \mathrm{df}=2, P=0.00)$ between nitrogen in the lower, middle and upper parts of the hill. Ikamiro, was however different, with the highest total nitrogen (4.0\%) in the upper part followed by the middle part with $2.5 \%$, and then the lower part had the lowest percentage (2.2\%) of the total nitrogen The total nitrogen between the lower, middle and upper parts of the Ikamiro hill showed a significant difference $(\mathrm{F}=64.385$, $\mathrm{df}=2, P=$ $0.00)$. And there was no significant difference $(P=0.12)$ between the lower and middle part parts (Table 3$)$. In Kacherere, the middle part had the highest percentage of total nitrogen $(2.0 \%)$ followed by the lower part with $1.5 \%$ of total nitrogen and the upper part had the lowest percent $(1.3 \%)$. There was a significant difference $(\mathrm{F}=$ $9.00, \mathrm{df}=2, P=0.02$ ) between nitrogen in the lower, middle and upper parts of the hill. However there was no significant difference $(P=0.28)$ between the lower and middle part parts (Table 3$)$.

The general trend for nitrogen content of the soil in the study area was, middle part < upper part < lower part. The total Nitrogen content of soil is directly associated with its organic content and its amount on cultivated soils [12] [36]. The lowest amount of nitrogen in lower parts of the hills depends on the concentration of water in the that section which discourages the nitrifying bacteria by preventing the availability of oxygen within the soil for example if there is water logging in the lower section there will be lower concentration of nitrogen [14]. This could have contributes to the slower decomposition of organic matter which is the main source of nitrogen. The higher total nitrogen in the upper part of some study sites could be due to different land use and soil management practices at the upper parts of the hill. A relatively higher amount of total nitrogen on the upper parts than on the lower ones could also be attributed to manuring or other soil management activities like improving the nitrogen content by growing leguminous plants that fix nitrogen from the air through the nodules of their roots practiced by the respective farmers. 
Table 3. Soil organic content in study area.

\begin{tabular}{cccc}
\hline Part of the Hills & OC(\%) in Karengyere & OC(\%) in Ikamiro & OC(\%) in Kacherere \\
\hline Upper & 0.12 & 0.24 & 0.11 \\
Middle & 0.21 & 0.17 & 0.17 \\
Lower & 0.18 & 0.19 & 0.13 \\
\hline
\end{tabular}

Source: Field data 2012.

\subsubsection{Available Soil Phosphorous Concentration}

Phosphorous was lowest in upper parts of the hill in Karengyere and Kacherere, as revealed by Table 4. However, the middle parts of the two hills have the greatest amount. For the two hills, the variation in phosphorous amounts is: Middle parts $>$ lower parts $>$ upper parts. There was a significant difference $(\mathrm{F}=3.251, \mathrm{df}=2, P=$ 0.00 ) between the available phosphorous concentration in the lower, middle and upper parts of Karengyere hill. And there was also a significant difference $(\mathrm{F}=8.448, \mathrm{df}=2, P=0.00)$ between pars of Kacherere hill. The trend for Ikamiro, was however different, with the highest organic matter content found on the upper part. The middle part of this transect had the higher amount phosphorous than the lower part just like the case for the Kacherere middle part. And there a significant difference $(\mathrm{F}=2.941, \mathrm{df}=2, P=0.00)$ between pars of Ikamiro hill.

In general, the order for phosphorous amounts was Middle parts $>$ lower parts > upper parts is lowest in upper part of the hill as revealed by Table 5, and which is in agreement with the findings of Tisdale et al. [36] and Vagen [37] who reported similar results in India and Ethiopia. The variation in available Phosphor between different parts of the hills could be due to washing out of the soil in the upper parts and accumulation at the middle parts. The erosional materials which tend to transport predominantly the clay and organic content fractions of the soil, which are relatively rich in Phosphorous fractions. This could also be because the rate of leaching is lowest in the middle parts due to relatively higher content of clay in the middle parts of these transects.

\subsubsection{Exchangeable Ions/Exchangeable Bases}

The mean relative abundance of basic cations of the exchangeable ions in the composite samples for all the sites in the study field was in the order of $\mathrm{Ca}^{2+}>\mathrm{Mg}^{2+}>\mathrm{K}^{+}>\mathrm{Na}^{+}$(Figure 10). For Karengyere and Kacherere the amount of these ions seems to rhyme well with the amount of organic matter (Table 2). The lower, middle and upper parts of the hill produced a significant difference $(\mathrm{F}=5.265 \mathrm{df}=2, P=0.00)$ among the concentration of exchangeable Potassium, Calcium and Magnesium ions, and no significant difference $(\mathrm{F}=0.429, \mathrm{df}=2, P=$ 0.67) among the concentration of Sodium exchangeable ion for all parts of the hills (Figure 10).

In Karengyere the middle and upper parts had similar concentration of potassium ions $(0.05 \mathrm{Cmols} / \mathrm{Kg})$ which was higher than the lower parts. Kacherere had the highest concentration of sodium exchangeable ion $(0.05$ Cmols $/ \mathrm{Kg}$ ) in the upper parts and lower parts. The middle parts had the lowest concentration of sodium exchangeable ion $(0.04 \mathrm{Cmols} / \mathrm{Kg})$. In Ikamiro the concentration of sodium exchangeable ion was highest $(0.05$ $\mathrm{Cmols} / \mathrm{Kg})$ in the upper parts and lowest $(0.03 \mathrm{Cmols} / \mathrm{Kg})$ in the middle parts.

In Karengyere the highest concentration of potassium ions $(0.51 \mathrm{Cmols} / \mathrm{Kg})$ was in the lower parts and the upper parts had lowest concentration of potassium ions $(0.20 \mathrm{Cmols} / \mathrm{Kg})$. Kacherere had the highest concentration of potassium exchangeable ion $(0.64 \mathrm{Cmols} / \mathrm{Kg})$ in the middle parts and lowest $(0.43 \mathrm{Cmols} / \mathrm{Kg})$ in the upper parts. In Ikamiro the concentration of potassium exchangeable ion was highest $(0.70 \mathrm{Cmols} / \mathrm{Kg})$ in the upper parts and lowest $(0.34 \mathrm{Cmols} / \mathrm{Kg})$ in the middle parts.

In Karengyere highest concentration of calcium ions $(4.0 \mathrm{Cmols} / \mathrm{Kg})$ was in the lower parts and the upper parts had lowest (2.2 Cmols/Kg). Ikamiro had the highest concentration of calcium exchangeable ion (3.2 $\mathrm{Cmols} / \mathrm{Kg})$ in the middle parts and lowest $(2.0 \mathrm{Cmols} / \mathrm{Kg})$ in the lower parts. In Kacherere the concentration of calcium exchangeable ion was highest $(5.0 \mathrm{Cmols} / \mathrm{Kg})$ in the middle parts and lowest $(2.0 \mathrm{Cmols} / \mathrm{Kg})$ in the lower parts.

In Karengyere the highest concentration of magnesium ions $(2.11 \mathrm{Cmols} / \mathrm{Kg})$ was in the lower parts and the upper parts had lowest $(1.02 \mathrm{Cmols} / \mathrm{Kg})$. Kacherere had the highest concentration of magnesium exchangeable ion $(2.04 \mathrm{Cmols} / \mathrm{Kg})$ in the middle parts and lowest $(1.02 \mathrm{Cmols} / \mathrm{Kg})$ in the lower parts. In Ikamiro the concentration of magnesium exchangeable ion was highest $(1.96 \mathrm{Cmols} / \mathrm{Kg})$ in the middle parts and lowest $(0.99$ $\mathrm{Cmols} / \mathrm{Kg})$ in the lower parts. In general, across all the three transects, divalent ions $\left(\mathrm{Ca}^{2+}\right.$ and $\left.\mathrm{Mg}^{2+}\right)$ were more abundant than mono-valent ones $\left(\mathrm{Na}^{+}\right.$and $\left.\mathrm{K}^{+}\right)$upper parts. 


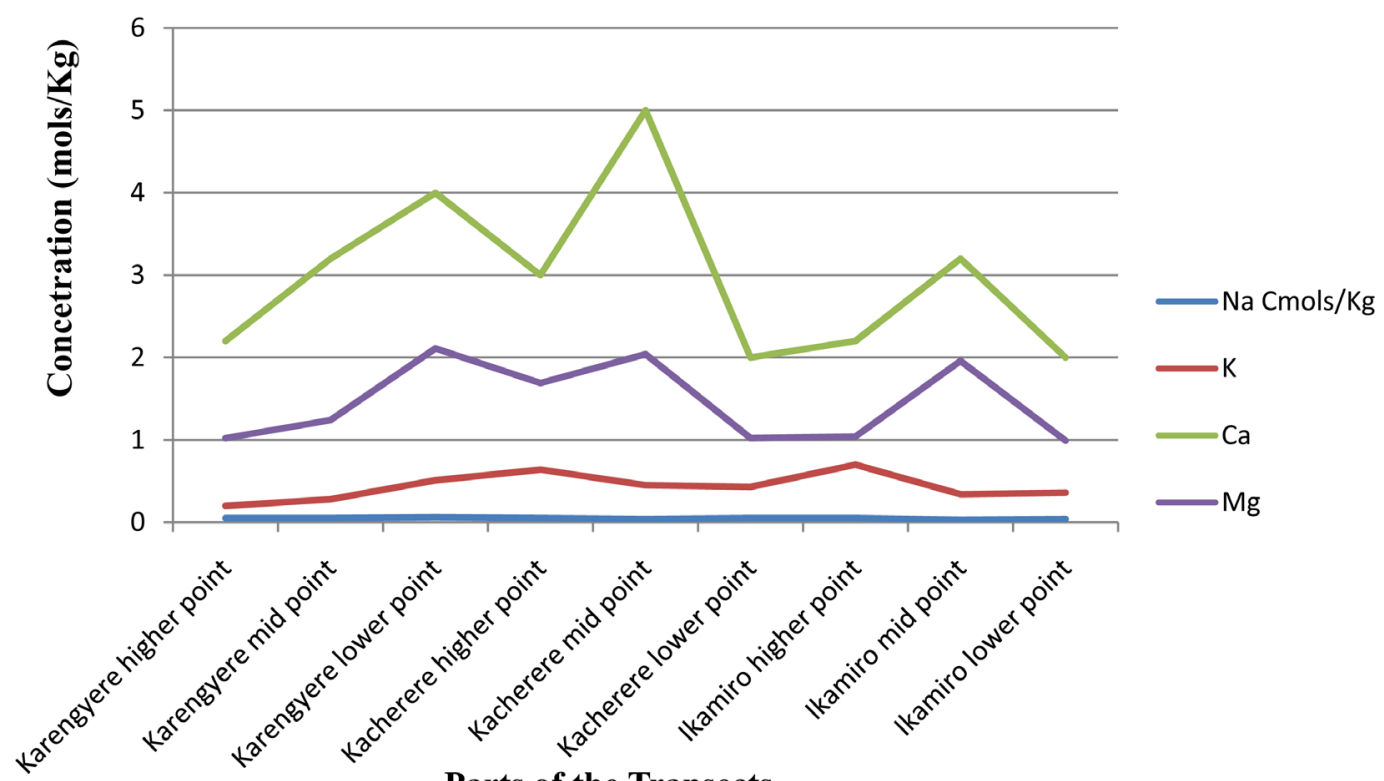

Parts of the Transects

Figure 10. Exchangeable ions/exchangeable bases in the study area. Source: Survey data, 2012.

Table 4. Total nitrogen of the study area.

\begin{tabular}{cccc}
\hline Part of the Hills & $\mathrm{N}(\%)$ in Karengyere & $\mathrm{N}(\%)$ in Ikamiro & $\mathrm{N}(\%)$ in Kacherere \\
\hline Upper & 1.4 & 4.0 & 1.3 \\
Middle & 3.6 & 2.5 & 2.0 \\
Lower & 2.8 & 2.2 & 1.5 \\
\hline
\end{tabular}

Source: Field data 2012.

Table 5. Available soil phosphorus concentration in the study area.

\begin{tabular}{cccc}
\hline Part of the Hills & $\mathrm{P}(\mathrm{ppm})$ in Karengyere & $\mathrm{P}(\mathrm{ppm})$ in Ikamiro & $\mathrm{P}(\mathrm{ppm})$ in Kacherere \\
\hline Upper & 0.52 & 5.47 & 0.22 \\
Middle & 2.47 & 3.52 & 7.20 \\
Lower & 4.50 & 1.35 & 0.52 \\
\hline
\end{tabular}

Source: Field data 2012.

The results of this study are in agreement with Tidele et al. [36] who found a significant difference in exchangeable bases among different soil from lowland and upland area in India.

Foth Ellis [21] found out that tropical soils on steep areas are deficient in $\mathrm{K}^{+}, \mathrm{Ca}^{2+}$ and $\mathrm{Mg}^{2+}$. This assertion is true for the four exchangeable cations $\left(\mathrm{Na}^{+}, \mathrm{K}^{+}, \mathrm{Ca}^{2+}, \mathrm{Mg}^{2+}\right)$ according to findings from Karengyere (Figure 10), but not necessarily the same about Ikamiro and Kacherere. For Karengyere, the amount of these ions seems to rhyme well with the amount of organic matter (Table 2). Organic matter at lower altitude decomposes quicker due to higher microbial activity of soil fauna facilitated by higher temperatures experienced at lower altitudes. It is from this decomposition that these exchangeable ions are released hence their abundance in the soil. For Ikamiro, the human settlement pattern was such that most of the people had their homesteads at the top of the hill. This implies a higher deposition of organic matter in form of compost manure at the top than in the middle part. The lower part however had higher exchangeable ion content probably due to water erosion which deposits the ions down the gradient.

In general, across all the three transects, divalent ions $\left(\mathrm{Ca}^{2+}\right.$ and $\left.\mathrm{Mg}^{2+}\right)$ were more abundant than mono-valent 
ones $\left(\mathrm{Na}^{+}\right.$and $\left.\mathrm{K}^{+}\right)$upper parts. This is probably because the former have lower cation exchange rate than the latter, and the latter are easily leached and can quickly evaporate compared to the divalent ones due to a difference in atomic mass. Therefore, in a climate with heavy rains and severe droughts, leaching and evaporation could explain the trends, which is also in agreement with Nearing et al. [7].

\subsubsection{Soil Texture of the Study Area}

Ikamiro hill had more clay (42\%) than sand (40\%) and silt (18\%) in the upper part. The lower part had more sand (48\%) than clay (36\%) less silt (16\%). The results are summarized in Figure 11. In Karengyere hill, middle part had more clay (40\%) than sand (36\%) while the upper part in the area had more sand (44\%) than clay (28\%) as indicated in Figure 11. Kacherere had more sand contents in all part than clay (Figure 11). In general, across the three transects, there was more sand at the lower parts than the middle and more clay at top parts. This could be because of water erosion which led to the middle parts having the lowest sand content compared to the other parts.

In general soil texture (based on sand content) was lower part > upper part > middle part. Lilienfein et al. [20], Foth and Ellis [21], and Binkley and Sollins [13] all agree that rough soil textures are associated with high altitude. These observations show that climate change in the form of heavier rains has facilitated erosion of soils where sandy ones are the most eroded (due to poor soil structure). In Karengyere middle part, had more clay than sand and it had more sand than clay in lower parts (Figure 11). Water erosion probably explains why we had more sand in the lower part of the hills since the lower part acts as a site for deposition. Climate variability and change (heavy rains) play an important role especially in terms of water erosion since the soils become saturated with water letting the excess spill over as run off. As the run offs builds up, it carries soil particles and organic matter later depositing them in lower lying areas.

For Ikamiro, the lower parts had highest amounts of sand, while the top were dominantly clay (Figure 11). This could be because of the nature of the parent rock from which the soil was formed, and the fact that some families had settled at the hill top. This settlement pattern implies that farming practices such as the application organic manure were crucial in determining the texture trend of the soil texture. Kacherere had more sand contents in all part than clay (Figure 11). This could be attributed to erosion, deposition, eluviations and weathering. This could also be because of extremes in environmental temperature which promote partial rock physical weathering, hence more sand is seen when the areas are cultivated before the particles of the newly formed soils are not yet covered with organic matter or after erosion has made the particles "bare" hence more visible in the sample.

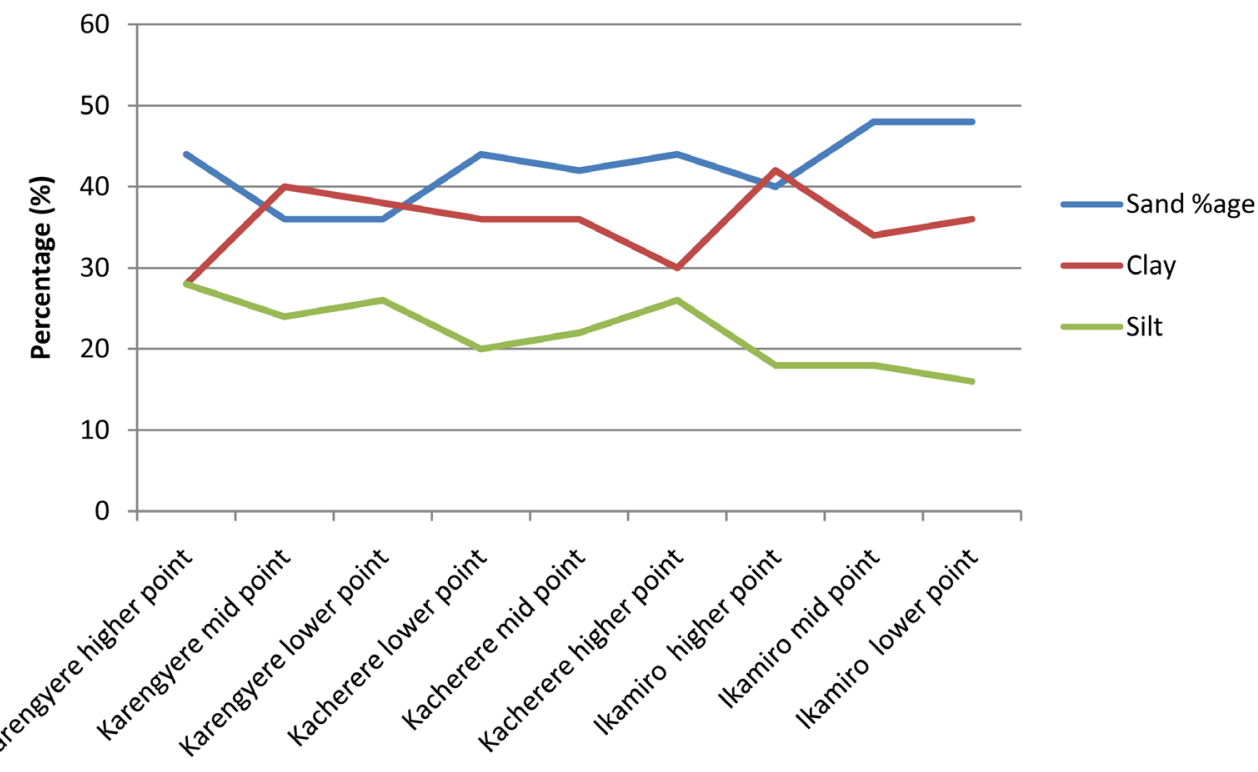

Parts of the Transects 


\subsection{Crop Productivity of Rural Farmers in Kigezi Highlands in Changing Climate}

The performances of major crops grown in the study sites were evaluated at lower, middle and upper parts hill by measuring their yields per hectare along the three transects in the study area.

\subsection{Crop Productivity of Selected Crops in Karengyere Parish, Muko Sub-County}

There was a significant difference between crop yields of lower, middle and upper parts of the hill ( $F=5.321$, $d f$ $=2, P=0.01$ ). However there was no significant difference between the crop yields of lower and middle parts $\left(\mathrm{P}=0.39\right.$ ).The yields measured at the lower point in Karengyere were; $20125.0 \mathrm{Kg} \cdot \mathrm{ha}^{-1}$ of Irish potatoes, 4375.0 $\mathrm{Kg} \cdot \mathrm{ha}^{-1}$ of beans and $2656.3 \mathrm{Kg} \cdot \mathrm{ha}^{-1}$ of sorghum. Yields measured in the middle part were $15468.8 \mathrm{Kg} \cdot \mathrm{ha}^{-1}$ of Irish potatoes, $2668.8 \mathrm{Kg} \cdot \mathrm{ha}^{-1}$ of beans, $14718.8 \mathrm{Kg} \cdot \mathrm{ha}^{-1}$ of sweet potatoes and $2593.8 \mathrm{Kg} \cdot \mathrm{ha}^{-1}$ of sorghums. Yields measured at the upper point were $5328.1 \mathrm{Kg} \cdot \mathrm{ha}^{-1}$ of Irish potatoes, $1890.6 \mathrm{Kg} \cdot \mathrm{ha}^{-1}$ of beans, and 7468.8 $\mathrm{Kg} \cdot \mathrm{ha}^{-1}$ of sweet potatoes (Figure 12). Higher yields were recorded at the lower part followed by middle and lowest in the upper parts. The findings from the study, Pender, et al. [25] and Asadi et al. [17] reveal that upper part of hills yield the least produce of all crops. This could have been due to the deficiency in Nitrogen, Phosphorous and Potassium in that upper part of the transect. The deficiency of the nutrients there could be associated with nutrient losses due to water erosion and leaching which is more in the upper parts than lower parts. This is evidence that the lower parts were a region of a deposition of nutrients from higher altitude. This deposition was a result of water erosion which is a function of heavy rains in the variable and changing climates experienced in the area. The variations in yields among different parts of the hills indicate variations in available soil nutrients, land use, farm management practices and field hygiene when other factors are constant during climate change and variability.

\subsection{Productivity of Selected Crops in Ikamiro Parish, Muko Sub-County}

In Ikamiro, there was a significant difference $(\mathrm{F}=7.420 \mathrm{df}=2, P=0.012$ ) between mean crop productivity of lower, middle and upper parts. And no significant difference $(P=0.13)$ between middle and upper parts The lower part had $15063.0 \mathrm{Kg} \cdot \mathrm{ha}^{-1}$ of Irish potatoes, $5893.8 \mathrm{Kg} \cdot \mathrm{ha}^{-1}$ of beans and $6562.5 \mathrm{Kg} \cdot \mathrm{ha}^{-1}$ of sorghum. The middle point had $10000.0 \mathrm{Kg} \cdot \mathrm{ha}^{-1}$ of Irish potatoes, $2546.6 \mathrm{Kg} \cdot \mathrm{ha}^{-1}$ of beans, and $12093.8 \mathrm{Kg} \cdot \mathrm{ha}^{-1}$ of sweet potatoes and $2375.0 \mathrm{Kg}^{-1} \mathrm{ha}^{-1}$ of sorghum. The average crop yields measured at the upper points were: 21938.0 $\mathrm{Kg} \cdot \mathrm{ha}^{-1}$ of Irish potatoes, $4875 \mathrm{Kg} \cdot \mathrm{ha}^{-1}$ of beans $16250.0 \mathrm{Kg} \cdot \mathrm{ha}^{-1}$ of sweet potatoes and $2781.3 \mathrm{Kg} \cdot \mathrm{ha}^{-1}$ of sorghum respectively. The results are summarized in Figure 13. This finding does not agree with IPCC [3], and Pender, et al. [25] who appreciated the effect of rare and insufficient rains as a major cause of reduced crop yield. It is probable that farming practices such as application of organic manure could have led to

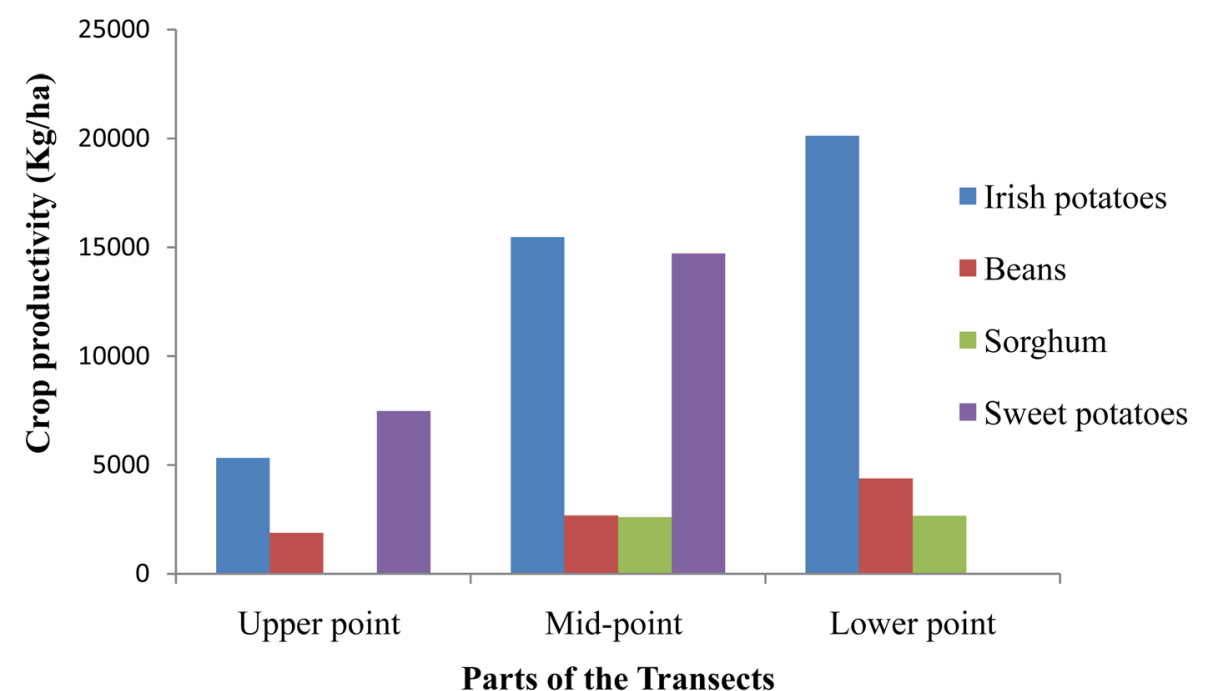

Figure 12. Crop productivity of selected crops in Karengyere parish, Muko Sub-County. Source: Field data 2012. 


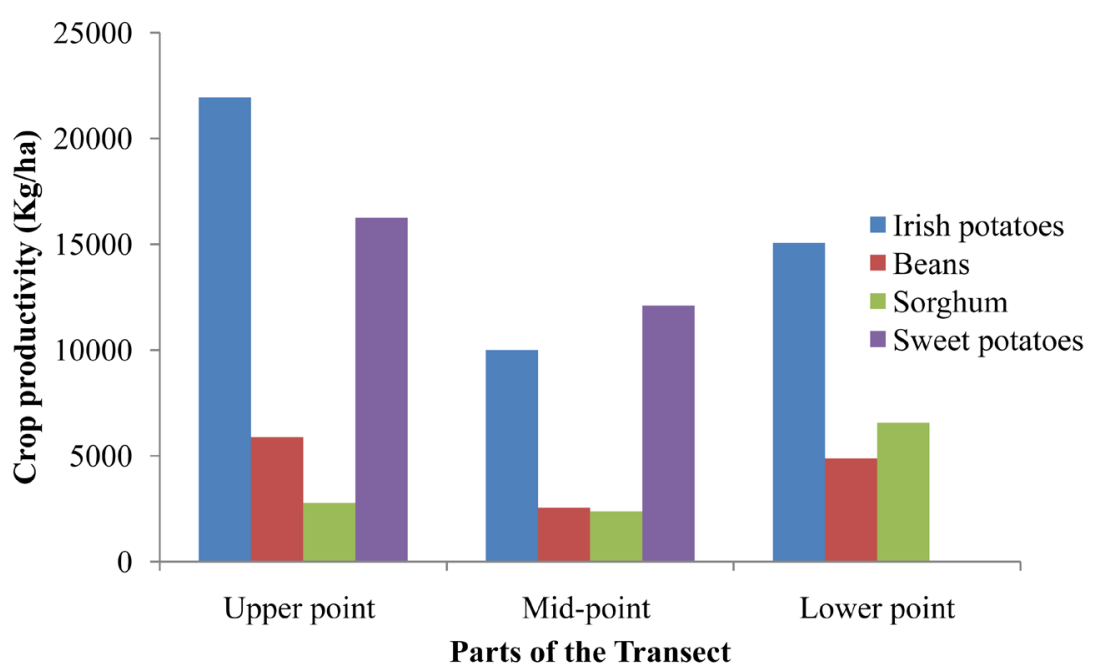

Figure 13. Crop productivity of selected crops in Ikamiro parish, Muko Sub-County. Source: Field data 2012.

this trend in production. Although farmers could ordinarily apply organic manure, they may have to do it even more since they are aware that their area is susceptible to erosion.

The lower part was more fertile than middle part, leading to high yield of all crops. This could be because the lower end receives erosion material from the upper parts of the hill. The resulting high organic matter content leads to higher concentration of mono-valent exchangeable ions $\left(\mathrm{Na}^{+}\right.$and $\left.\mathrm{K}^{+}\right)$which is an attribute of an area experiencing climate variability and change [17]. The middle part of Ikamiro was the least productive (Figure 13). This could be due to the high rates of mineral leaching and water erosion since the soils there are mainly sandy in nature (Figure 11). This possibly explains why the crop yields there were the least. This indicates that the higher parts in Ikamiro were more productive, followed by the lower parts and the middle parts. The higher productivity in the upper parts of Ikamiro was probably due to higher concentration of Nitrogen (4.0\%), Phosphorous $(5.4 \mathrm{ppm})$, Potassium $(0.70 \mathrm{Cmol} / \mathrm{Kg})$ and Organic matter $(0.24 \%)$.

\subsection{Crop Productivity of Selected Crops in Kacherere Parish, Bufundi Sub-County}

In Kacherere the lower, middle and upper parts had no significant difference $(\mathrm{F}=1.747, \mathrm{df}=2, \mathrm{P}=0.23$ ) between mean value of crop yields. The lower parts had $5578.0 \mathrm{Kg} \cdot \mathrm{ha}^{-1}$ of 1rish potatoes, $2234.4 \mathrm{Kg} \cdot \mathrm{ha}^{-1}$ of beans and $2312.5 \mathrm{Kg} \cdot \mathrm{ha}^{-1}$ of sorghum. The middle part had $6656.3 \mathrm{Kg} \cdot \mathrm{ha}^{-1}$ of Irish potatoes, $2421.9 \mathrm{Kg} \cdot \mathrm{ha}^{-1}$ of beans, $4250.0 \mathrm{Kg} \cdot \mathrm{ha}^{-1}$ of sweet potatoes and $2375 \mathrm{Kg} \cdot \mathrm{ha}^{-1}$ of sorghum, respective. The upper parts had $6171.9 \mathrm{Kg} \cdot \mathrm{ha}^{-1}$ of Irish potatoes, $2406.3 \mathrm{Kg} \cdot \mathrm{ha}^{-1}$ of beans, $7250.0 \mathrm{Kg} \cdot \mathrm{ha}^{-1}$ of sweet potatoes, and $5718.0 \mathrm{Kg} \cdot \mathrm{ha}^{-1}$ of sorghum (Figure 14). However, the middle parts were the most productive parts in Kacherere, followed by the upper parts. The lower parts were the least productive. The findings from the study area (Figure 14) showed that the upper and middle parts were more fertile than the lower part. This is contrary to assertions by Asadi et al. [17], IPCC [3], Siriri [19], and Pender, et al. [25]. These scholars suggested more crop yield on the lower parts of the hill than upper parts. Such an anomalous situation could be as a result of the higher usage of fertilizers and organic manures on the middle and upper parts. Low productivity in the lower parts could be due soil exhaustion since farmers initially cultivate these parts before abandoning them for more fertile land [10]. Some farmers could have abandoned the lower lying areas in fear of floods that would easily destroy the crops.

\subsection{Crops Grown in Different Level of the Slops in the Study Area}

From the study, most of the gardens observed had annual crops. These were; sorghum (Sorghum vulgare), Irish potatoes (Solanum tuberosum), sweet potatoes (Ipomoea batatas), maize (Zea mays), beans (Phaseolus vulgaris) and other annual crops. Lowlands and middle parts were dominated by Irish potatoes, beans and some sorghum. However, sweet potatoes were not grown in the lowlands, they were only observed in gardens in the middle parts and even more common in hill tops (Figure 15) corresponding to areas with relatively high content of clay 


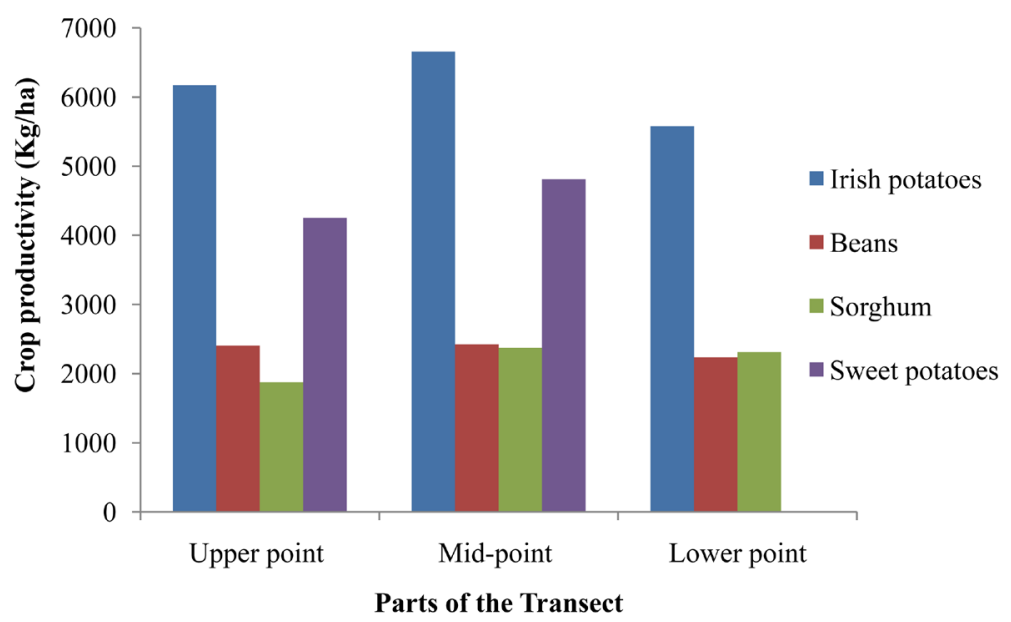

Figure 14. Productivity for selected crops in Kacherere parish, Bufundi Sub-County. Source: Field data 2012.

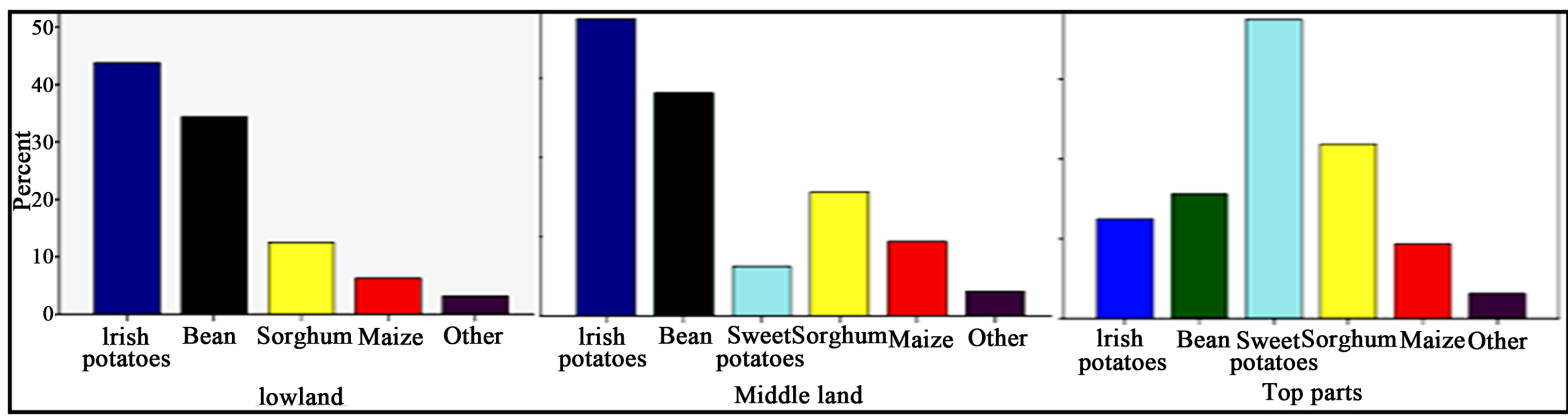

Figure 15. Common crops grown in lower, middle and upper level in the study area. Source: Field data 2012.

soil as shown in Figure 11. This is in agreement with results of Mbabazi et al. [38] in a study on participatory land degradation in Kabale district. They found that arable farming was practiced on the lowlands, on the slopes and on the hill tops with main crops grown being annuals (sorghum, Irish potatoes, sweet potatoes, maize, beans, peas, finger millet and vegetables).

\section{Conclusions}

The study showed that there was significant variation of nutrients at the lower, middle and upper parts along altitudinal gradient. This could be due to the differences in soil erosion and leaching of soil nutrients, farming practices and varying adaptations to climate change and variability. This trend is evidence that climate change, land use and management practices indeed had great adverse effects on soil nutrient and texture status. The study also showed that middle parts of the transects had the highest concentration of most soil nutrients this could be because the middle parts could have been a deposition centre for some organic matter from the upper parts of the hill and lower lying areas are being affected by floods which affects the decomposition of organic matter which is the main source of nutrients.

Similarly, the middle parts of the study were the most fertile. This was majorly due to the high concentration of soil nutrient compositions in the middle parts. This indicates that crop yields were significantly affected by availability of soil nutrients along same gradient, attributable to the severity in soil erosion, nutrients leaching and farming practices.

\section{Acknowledgements}

Our deepest and sincere gratitude goes to the family of Ms. Fortunate Twagiramaria for having financially supported the activities of this study; and to the entire academic staff, Faculty of Science, Mbarara University of Science and Technology, for the advice and useful insights which enabled successful execution of this study. 


\section{References}

[1] Bagoora, F.K. (2010) Challenges of Climate Change in Mountain Ecosystems in Africa. National Environment Management Authority (NEMA), Kampala. An Overview Presentation at the Side Event Organized Mountain Alliance Initiative, United Nations Climate Change Conference COP16 and CMP6, Cancun Mexico, 2010, 29 p.

[2] World Bank (2010) Disaster Risk Management in a Changing Climate. The World Bank, Washington DC.

[3] IPCC (2007) Climate Change 2007: Synthesis Report. Contribution of Working Groups I, II and III to the Fourth Assessment Report of the Intergovernmental Panel on Climate Change [Core Writing Team, Pachauri, R.K and Reisinger, A., Eds.]. IPCC, Geneva, 104 p.

[4] Brklacich, M., Chazan, M. and Bohle, H.G. (2010) Human Security, Vulnerability and Global Environmental Change. In: Matthew, R.A., Barnett, J., Matthew, R.A. and O’Brien, K.L., Eds., Global Environmental Change and Human Security: An Introduction, The MIT Press, Cambridge, 35-52.

[5] UK Climate Impacts Program (UKCIP) (2009) Understanding Climate Change. http://www.ukcip.org.uk

[6] Aklilu, A. and Alebachew, A. (2009) Assessment of Climate Change Induced Hazards, Impacts and Responses in the Southern Lowlands of Ethiopia. FSS Research Report No. 4.

[7] Nearing, M.A., Prusk, F.F. and O’neal, M.R. (2004) Expected Climate Change Impacts on Soil Erosion Rate: Conservation Implication on Climate Change. Journal of Soil and Water Conservation, 5, 47-49.

[8] Mati, B.M. (2005) Overview of Water and Soil Nutrient Management under Smallholder Rain-Fed Agriculture in East Africa. Working Paper 105, Colombo, Sri Lanka.

[9] Republic of Uganda (2007) Climate Change. Uganda National Adaptation Programs of Action in Association with Environmental Alert, GEF and UNEP.

[10] Bamwerinde, W., Bashaasha, B., Ssembajjwe, W. and Peace, F. (2005) Determinants of Land Use in Kigezi Highlands of Southwestern Uganda. Forestry Research Resources Institute of the National Agricultural Research Organization, P.O Box 311, Kabale, Uganda; Department of Agricultural Economics and Agribusiness, Faculty of Agriculture, Makerere University, P.O. Box 7062, Kampala, Uganda. African Crop Science Conference Proceedings; 2005: Vol. 7.

[11] Enyewe, A. and Akalu, T. (2010) Effects of Long-Term Soil and Water Conservation on Agricultural Productivity: A Case Study of Anjeni Watershed. In: Bancy, M., Ed., Agricultural Water Management Interventions Bearing Returns on Investment in Eastern and Southern Africa: A Compendium of 18 Case Studies from Six Countries in Eastern and Southern Africa, IMAWESA Working Paper 17, 28-39.

[12] Mengele, K. and Kirby, E.A. (1987) Principles of Plant Nutrition. Panima Publishers Corporation, New Delhi.

[13] Binkley, D. and Sollins, P. (1990) Factors Determining Differences in Soil pH in Adjacent Conifer and Alder-Conifer Stands. Soil Science Society of America Journal, 54, 1427-1433.

[14] Mulugeta, D. and Stahr, K. (2010) Assessment of Integrated Soil and Water Conservation Measures on Key Soil Properties in South Gondar, North-Western Highlands of Ethiopia. Journal of Soil Science and Environmental Management, 1, 164-176. http://dx.doi.org/10.1007/s00267-008-9157-8

[15] Nkonya, E.M., Pender, J.P., Sserunkuuma, D. and Jagger, P. (2002) Development Pathways and Land Management in Uganda. Proceedings of the Conference on Policies for Land Management in the East African Highlands, United Nations Economic Commission for Africa (ECA), Addis Ababa, 24-26 April 2002.

[16] Ministry of Water and Environment (2007) National Adaptation Program of Actions. Department of Meteorology, Government of Uganda.

[17] Asadi, H., Raeisvandi, A., Rabiei, B. and Ghadiri, H. (2011) Effect of Land Use and Topography on Soil Properties and Agronomic Productivity on Calcareous Soils of a Semi-Arid Region, Iran. Land Degradation and Development, 23, 496-504. http://dx.doi.org/10.1002/ldr.1081

[18] Carswell, G. (2004) Soil Conservation in Colonial Kigezi Uganda. In: Beinart, W. and McGregor, J., Eds., Social History \& African Environments, Heinemann and James Currey, Oxford.

[19] Siriri, D., Tanya, M.M., Rousse, T. and Sake, J.K. (2005) Crop and Soil Variability on Terraces in the Highlands of SW Uganda. Land Degradation and Development, 16, 569-579. http://dx.doi.org/10.1002/ldr.68

[20] Lilienfein, J.W., Wilcke, M.A., Ayarza, L., Vilela, S.D., Lima, C. and Zech, W. (2000) Chemical Fractionation of Phosphorus, Sulphur, and Molybdenum in Brazilian Savannah Oxisols under Different Land Uses. Geoderma, 96, 3146.

[21] Foth, H.D. and Ellis, B.G. (1997) Soil Fertility. 2nd Edition, Lewis CRC Press LLC, Boca Raton, 290 p.

[22] Hamilton, A.C., Taylor, D., and Vogel, J. (1986) Early Clearance and Environmental Degradation in Southwest Uganda. Nature, 320, 164-167.

[23] Food and Agricultural Organization (FAO) (2004) Monitoring Progress towards the World Food Summit and Millen- 
nium Development Goals. The State of Food Insecurity Report. Food and Agriculture Organization of the United Nations, Vialedelle Terme di Caracalla, Rome.

[24] Uganda National Adaptation Programme of Action (NAPA) (2007) Climate Change: Environmental Alert, GEF, UNEP and Republic of Uganda. http://unfccc.int/resource/docs/napa/uga01.pdf

[25] Pender, J.P., Jagger, N.E. and Sserunkuuma, D. (2001) Development Pathways and Land Management in Uganda: Causes and Implications. EPTD Discussion Paper No. 85, International Food Policy Research Institute, Washington DC.

[26] Langlands, B. (1971) Population Geography of Kigezi. Occasional Paper 22, Department of Geography, Makerere.

[27] Ministry of Natural Resources (1998) Wetland Status Report for Kabale District. Kampala.

[28] Banana, A.Y. and Tweheyo, M. (2004) Ecological Changes Following Rules in Use and Anthropology; the Case of Echuya Bamboo Forest, South-Western Uganda. Department of Forest Product Engineering, Makerere University, Kampala; Department of Forest Biology and Ecosystems Management, Makerere University, Kampala. Uganda Journal, 50, 39-49.

[29] Kabale District Meteorological Department (2011) Temperatures and Rainfall for Stations in Kabale.

[30] Van Reeuwijk, L.P. (1992) Procedures for Soil Analysis. 3rd Edition, International Soil. Reference and Information Center (ISRIC), Wageningen, $34 \mathrm{p}$.

[31] Walkley, A. and Black, I.A. (1934) An Examination of the Degtjareff Method for Determining Soil Organic Matter and a Proposed Modification of the Chromic Acid Titration Method. Soil Science, 37, 29-38.

[32] Olsen, S.R., Cole, C.V., Watanable F.S. and Dean, L.A. (1954) Estimation of Available Phosphorus in Soil by Extraction with Sodium Bicarbonate. USDA Circular, 939, 1-19.

[33] Chapman, H.D. (1965) Cation Exchange Capacity. In: Black, C.A., Ensminger, L.E. and Clark, F.E., Eds., Methods of Soil Analysis, American Society of Agronomy, Inc., Madison, 891-901.

[34] Desanker, P.V. and Magadza, C. (2001) Africa. In: McCarthy, J.J., Canziani, O.F., Leary, N.A., Doken, D.J. and White, K.S., Eds., Climate Change 2001: Impacts, Adaptation and Vulnerability, IPCC Working Group II, Third Assessment Report. Cambridge University Press.

[35] Rugumayo, E.B. (2011) Small Holder Farmers’ Knowledge and Adaptation to Climate Change in the Rwenzori Region. Research Report Number 001 in March, Kabarole Research and Resource Centre (KRC), Fort Portal.

[36] Tisdale, S.L., Nelson, W.L., Beaton, J.D. and Havlin, J.L. (1995) Soil Fertility and Fertilizer. 5th Edition, Prentice-Hall of India, New Delhi, 684 p.

[37] Vagen, T.G. (1996) Phosphorus Status in Soils from Terraced and UN-Terraced Land on Highly Eroded Slopes in Tigray, Ethiopia. Master’s Thesis, Agricultural University of Norway, Norway.

[38] Mbabazi, P., Bagyenda, R. and Muzira, R. (2012) Participatory Land Degradation Assessment in the Highlands of Kabale District, Southwestern Uganda. A Report Submitted to 937 Third RUFORUM Biennial Meeting 24-28 September 2012, Entebbe, Uganda. African Highlands Initiative (AHI), Natural Resources Systems Programme, Final Technical Report R7856. 
Appendix 1. Crop productivity of selected crops in Karengyere parish.

\begin{tabular}{|c|c|c|c|c|c|c|c|c|c|}
\hline \multirow{2}{*}{ Location } & \multirow{2}{*}{ Position } & \multirow{2}{*}{ Crop types } & \multirow{2}{*}{$\begin{array}{l}\text { Number } \\
\text { of plots }\end{array}$} & \multicolumn{4}{|c|}{ Yield/plot (Kg) } & \multirow{2}{*}{ Mean yield/kg } & \multirow{2}{*}{$\begin{array}{l}\text { Yields in } \\
\text { Kg.ha }^{-1}\end{array}$} \\
\hline & & & & \multicolumn{2}{|c|}{ 1st season } & \multicolumn{2}{|c|}{ 2nd season } & & \\
\hline \multirow{3}{*}{ pper point } & \multirow{3}{*}{$\begin{array}{l}\text { S } 01^{\circ} 13 ' 32.0^{\prime \prime} \\
\text { E } 029^{\circ} 48^{\prime} 20.7^{\prime \prime}\end{array}$} & Irish potatoes & 4 & 08.3 & 06.7 & 10.0 & 09.1 & 8.52 & 5328.1 \\
\hline & & Beans & 4 & 03.5 & 04.0 & 02.4 & 02.2 & 3.00 & 1890.6 \\
\hline & & Sweet potatoes & 2 & & & 11.6 & 12.3 & 11.95 & 7468.8 \\
\hline \multirow{4}{*}{ Mid-point } & \multirow{4}{*}{$\begin{array}{l}\text { S } 01^{\circ} 13^{\prime} 30.8^{\prime \prime} \\
\text { E } 29^{\circ} 48^{\prime 2} 27.7^{\prime \prime}\end{array}$} & Irish potatoes & 4 & 15.1 & 10.8 & 37.5 & 35.6 & 24.75 & 15468.8 \\
\hline & & Beans & 4 & 06.0 & 05.5 & 04.0 & 03.5 & 4.75 & 2668.8 \\
\hline & & Sweet potatoes & 2 & & & 25.7 & 21.4 & 23.6 & 14718.8 \\
\hline & & Sorghum & 2 & 04.0 & 04.3 & & & 08.50 & 2593.8 \\
\hline \multirow{3}{*}{$\begin{array}{l}\text { Lower } \\
\text { point }\end{array}$} & \multirow{3}{*}{ S $01^{\circ} 13^{\prime} 28.3^{\prime \prime}$} & Irish potatoes & 4 & 35.0 & 33.5 & 26.5 & 33.8 & 64.55 & 20125.0 \\
\hline & & Beans & 4 & 11.0 & 09.0 & 03.8 & 04.2 & 7.00 & 4375.0 \\
\hline & & Sorghum & 2 & 05.0 & 03.5 & & & 4.25 & 2656.3 \\
\hline
\end{tabular}

Source: Survey data, 2012.

Appendix 2. Crop productivity of selected crops in Ikamiro parish.

\begin{tabular}{|c|c|c|c|c|c|c|c|c|c|}
\hline \multirow{3}{*}{ Location } & \multirow{3}{*}{ position } & \multirow{3}{*}{$\begin{array}{c}\text { Crop types } \\
\text { Irish potatoes }\end{array}$} & \multirow{3}{*}{$\begin{array}{c}\text { Number } \\
\text { of plots }\end{array}$} & \multicolumn{4}{|c|}{ Yield/plot (Kg) } & \multirow{3}{*}{$\begin{array}{c}\text { Mean yield/kg } \\
35.10\end{array}$} & \multirow{3}{*}{$\begin{array}{l}\begin{array}{l}\text { Yields in } \\
\text { Kg}^{-1} \mathbf{h a}^{-1}\end{array} \\
21938.0\end{array}$} \\
\hline & & & & \multicolumn{2}{|c|}{ 1st season } & \multicolumn{2}{|c|}{ 2nd season } & & \\
\hline & & & & 36.0 & 27.0 & 46.0 & 31.3 & & \\
\hline \multirow{3}{*}{ Upper point } & \multirow{3}{*}{$\begin{array}{c}\text { S } 01^{\circ} 15^{\prime} 20.5^{\prime \prime} \\
\text { E } 029^{\circ} 49^{\prime} 21.3^{\prime \prime}\end{array}$} & Beans & 4 & 11.0 & 07.2 & 08.6 & 04.6 & 07.80 & 4875.0 \\
\hline & & Sweet potatoes & 2 & & & 29.0 & 23.4 & 26.00 & 16250.0 \\
\hline & & Sorghum & 2 & 04.0 & 04.9 & & & 04.45 & 2781.3 \\
\hline \multirow{4}{*}{ Mid-point } & \multirow{4}{*}{$\begin{array}{l}\text { S } 01^{\circ} 15^{\prime} 24.4^{\prime \prime} \\
\text { E } 29^{\circ} 49^{\prime} 5.1^{\prime \prime}\end{array}$} & Irish potatoes & 4 & 13.3 & 12.7 & 19.0 & 18.9 & 16.00 & 10000.0 \\
\hline & & Beans & 4 & 05.0 & 04.6 & 03.2 & 03.5 & 04.07 & 2546.6 \\
\hline & & Sweet potatoes & 2 & & & 22.0 & 16.7 & 19.35 & 12093.8 \\
\hline & & Sorghum & 2 & 03.9 & 03.7 & & & 03.80 & 2375 \\
\hline \multirow{3}{*}{ Lower point } & \multirow{3}{*}{ S $01^{\circ} 15^{\prime} 25.5^{\prime \prime}$} & Irish potatoes & 4 & 31.6 & 30.4 & 20.0 & 14.2 & 24.10 & 15063 \\
\hline & & Beans & 4 & 16.0 & 12.0 & 06.3 & 03.4 & 09.43 & 5893.8 \\
\hline & & Sorghum & 2 & 11.0 & 09.8 & & & 10.50 & 6562.5 \\
\hline
\end{tabular}

Source: Survey data, 2012.

Appendix 3. Crop productivity of selected crops in Kacherere parish.

\begin{tabular}{|c|c|c|c|c|c|c|c|c|c|}
\hline \multirow{2}{*}{ Location } & \multirow{2}{*}{ Position } & \multirow{2}{*}{ Crop types } & \multirow{2}{*}{$\begin{array}{c}\text { Number of } \\
\text { plots }\end{array}$} & \multicolumn{4}{|c|}{ Yields/plot/Kg } & \multirow[t]{2}{*}{ Mean yield $/ \mathrm{kg}$} & \multirow[t]{2}{*}{ Yields in $\mathrm{Kg} \cdot \mathrm{ha}^{-1}$} \\
\hline & & & & \multicolumn{2}{|c|}{ 1st season } & \multicolumn{2}{|c|}{ 2nd season } & & \\
\hline \multirow{4}{*}{ Upper point } & \multirow{4}{*}{$\begin{array}{c}\text { S } 01^{\circ} 16^{\prime} 40.8^{\prime \prime} \\
\text { E } 029^{\circ} 49^{\prime} 50.6^{\prime \prime}\end{array}$} & Irish potatoes & 4 & 11.2 & 10.3 & 08.8 & 09.2 & 9.88 & 6171.9 \\
\hline & & Beans & 4 & 04.5 & 05.0 & 03.2 & 02.7 & 3.85 & 2406.3 \\
\hline & & Sweet potatoes & 2 & & & 11.0 & 12.4 & 11.6 & 7250.0 \\
\hline & & Sorghum & 2 & 03.6 & 02.4 & & & 03.00 & 1875 \\
\hline \multirow{4}{*}{ Mid-point } & \multirow{4}{*}{$\begin{array}{l}\text { S } 01^{\circ} 16^{\prime} 39.9^{\prime \prime} \\
\text { E } 29^{\circ} 49^{\prime} 53.2^{\prime \prime}\end{array}$} & Irish potatoes & 4 & 10.0 & 08.4 & 07.5 & 05.0 & 7.73 & 6656.3 \\
\hline & & Beans & 4 & 04.6 & 05.0 & 03.1 & 02.8 & 3.88 & 2421.9 \\
\hline & & Sweet potatoes & 2 & & & 28.0 & 25.3 & 26.40 & 4250.0 \\
\hline & & Sorghum & 2 & 04.1 & 03.5 & & & 03.80 & 2375.0 \\
\hline \multirow{3}{*}{$\begin{array}{l}\text { Lower } \\
\text { point }\end{array}$} & \multirow{3}{*}{ S $01^{\circ} 16 ' 37.5^{\prime \prime}$} & Irish potatoes & 4 & 11.0 & 09.2 & 07.5 & 8.0 & 14.08 & 5578.1 \\
\hline & & Beans & 4 & 04.8 & 03.7 & 02.8 & 03.0 & 3.58 & 2234.4 \\
\hline & & Sorghum & 2 & 03.1 & 04.3 & & & 3.70 & 2312.5 \\
\hline
\end{tabular}

Source: Survey data, 2012. 